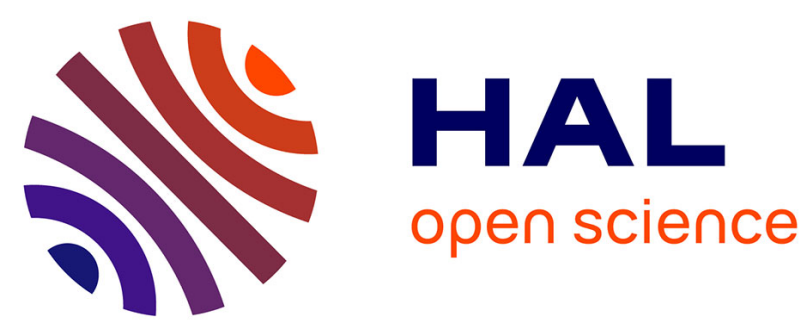

\title{
Draa Sfar, Morocco: A Visean (331 Ma) pyrrhotite-rich, polymetallic volcanogenic massive sulphide deposit in a Hercynian sediment-dominant terrane
}

\author{
Eric Marcoux, Abdelhay Belkabir, Harold L. Gibson, David Lentz, Gilles
} Ruffet

\section{To cite this version:}

Eric Marcoux, Abdelhay Belkabir, Harold L. Gibson, David Lentz, Gilles Ruffet. Draa Sfar, Morocco: A Visean (331 Ma) pyrrhotite-rich, polymetallic volcanogenic massive sulphide deposit in a Hercynian sediment-dominant terrane. Ore Geology Reviews, 2008, 33 (3-4), pp.307-328. 10.1016/j.oregeorev.2007.03.004 . insu-00192032

\section{HAL Id: insu-00192032 \\ https://hal-insu.archives-ouvertes.fr/insu-00192032}

Submitted on 26 Nov 2007

HAL is a multi-disciplinary open access archive for the deposit and dissemination of scientific research documents, whether they are published or not. The documents may come from teaching and research institutions in France or abroad, or from public or private research centers.
L'archive ouverte pluridisciplinaire HAL, est destinée au dépôt et à la diffusion de documents scientifiques de niveau recherche, publiés ou non, émanant des établissements d'enseignement et de recherche français ou étrangers, des laboratoires publics ou privés. 


\title{
Draa Sfar, Morocco: A Visean (331 Ma) pyrrhotite-rich, polymetallic volcanogenic massive sulphide deposit in a Hercynian sediment-dominant terrane
}

\author{
Eric Marcoux ${ }^{a}$, Abdelhay Belkabir ${ }^{b}$, Harold L. Gibson ${ }^{c}$, David Lentz ${ }^{d}$ and Gilles Ruffet ${ }^{e}$ \\ ${ }^{a}$ Géosciences, Institut des Sciences de la Terre d'Orléans (ISTO), Université d'Orléans BP \\ 6749,45067 Orléans cedex 2, France \\ ${ }^{\text {b}}$ Département des Sciences de la terre, Faculté des Sciences et Techniques de Guéliz, BP 549, \\ Av. Abdelkrim elkhattabi, Marrakech, Morocco \\ ${ }^{\mathrm{c}}$ Mineral Exploration Research Centre, Department of Earth Sciences, Laurentian University, \\ Sudbury Ontario, Canada P3E 2C6 \\ ${ }^{\mathrm{d}}$ Department of Geology, University of New Brunswick, Fredericton, NB, Canada E3B 5A3 \\ ${ }^{\mathrm{e}}$ Géosciences Rennes, UMR CNRS 6118, Campus de Beaulieu, Université de Rennes1, 35042 \\ Rennes Cedex, France
}

\begin{abstract}
Draa Sfar is a Visean, stratabound, volcanogenic massive sulphide ore deposit hosted by a Hercynian carbonaceous, black shale-rich succession of the Jebilet terrane, Morocco. The ore deposit contains $10 \mathrm{Mt}$ grading $5.3 \mathrm{wt} . \% \mathrm{Zn}, 2 \mathrm{wt} . \% \mathrm{~Pb}$, and $0.3 \mathrm{wt} . \% \mathrm{Cu}$ within two main massive sulphides orebodies, Tazakourt (Zn-rich) and Sidi M'Barek ( $\mathrm{Zn}-\mathrm{Cu}$ rich). Pyrrhotite is by far the dominant sulphide ( 70 to $95 \%$ of total sulphides), sphalerite is fairly abundant, chalcopyrite and galena are accessory, pyrite, arsenopyrite and bismuth minerals are rare. Pyrrhotite is monoclinic and mineralogical criteria indicate that it is of primary origin and not formed during metamorphism. Its composition is very homogeneous, close to $\mathrm{Fe}_{7} \mathrm{~S}_{8}$, and its absolute magnetic susceptibility is $2.10^{-3} \mathrm{SI} / \mathrm{g}$. Ar-Ar dating of hydrothermal sericites from a coherent rhyolite flow or dome within the immediate deposit footwall indicates an age of $331.7 \pm 7.9 \mathrm{Ma}$ for the Draa Sfar deposit and rhyolite volcanism.
\end{abstract}

The Draa Sfar deposit has undergone a low-grade regional metamorphic event that caused pervasive recrystallization, followed by a ductile-brittle deformation event that has locally imparted a mylonitic texture to the sulphides and, in part, is responsible for the elongated and sheet-like morphology of the sulphide orebodies. Lead isotope data fall into two compositional end-members. The least radiogenic end-member, $\left({ }^{206} \mathrm{~Pb} /{ }^{204} \mathrm{~Pb}=18.28\right)$, is characteristic of the Tazakourt orebody, whereas the more radiogenic end-member $\left({ }^{206} \mathrm{~Pb} /{ }^{204} \mathrm{~Pb}\right.$ 18.80) is associated with the Sidi M'Barek orebody, giving a mixing trend between the two end-members. Lead isotope compositions at Draa Sfar testify to a significant continental crust source for the base metals, but are different than those of the Hajar and South Iberian Pyrite Belt VMS deposits.

The abundance of pyrrhotite versus pyrite in the orebodies is attributed to low $f \mathrm{O}_{2}$ conditions and neither a high temperature nor a low $\mathrm{aH}_{2} \mathrm{~S}$ (below $10^{-3}$ ) is required. The highly anoxic conditions required to stabilize pyrrhotite over pyrite are consistent with formation of the deposit within a restricted, sediment-starved, anoxic basin characterized by the deposition of carbonaceous, pelagic sediments along the flank of a rhyolitic flow-dome complex that was buried by pelitic sediments. Deposition of sulphides likely occurred at and below the seafloor within anoxic and carbonaceous muds. 
Draa Sfar and other Moroccan volcanogenic massive sulphide deposits occur in an epicontinental volcanic domain within the outer zone of the Hercynian belt and formed within a sedimentary environment that has a high pelagic component. In spite of the diachronous emplacement between the IPB deposits (late Devonian to Visean) and Moroccan deposits (Dinantian), all were formed around $340 \pm 10 \mathrm{Ma}$ following a major phase of the Devonian compression.

Keywords: Massive sulphide deposit; Pyrrhotite; Draa Sfar; Morocco; Hercynian

\section{Introduction}

Recent exploration conducted by REMINEX in the Jebilet and Guemassa terranes of Morocco, as well as the commencement of mining at the Draa Sfar deposit, has resulted in increased accessibility to the deposit and its host rocks allowing new data to be obtained from underground and surface mapping and from drill core. This new data for the Draa Sfar deposit has significant implications for all of the sparsely documented volcanogenic massive sulphide (VMS) deposits in the Jebilet and Guemassa terranes of Morocco.

A companion paper by Belkabir et al. (2007-this issue) focuses on the geology, structure, volcanic environment and hydrothermal alteration at Draa Sfar. In this paper we focus on the Draa Sfar sulphide deposit that ranks second for $\mathrm{Zn}$ production in Morocco. We also describe the geological, mineralogical and lead isotopic characteristics of the sulphide deposit and propose a new model that may be applicable to other VMS deposits in the Jebilet and Guemassa terranes.

With production at Draa Sfar just starting in September 2005, underground workings, drill core and surface outcrops provided excellent exposures of the deposit and of the volcanosedimentary lithofacies that underlie, host and overlie it. This access has allowed us to collect representative samples of the Draa Sfar orebodies as well as the host volcanic-sedimentary succession.

Drill cores through the orebody have been analyzed for major and trace elements in order to characterize the ores and to determine the distribution of base and precious metals. The ore mineralogy has been determined through detailed petrographic analysis of 50 samples, and Xray diffractometry (XRD), scanning electron microscopy (SEM), and electron probe microanalysis (EPMA) of these samples. Fifteen lead isotope analyses were obtained on representative samples of the various ore facies in order to better constraint the source of metals and genesis of the massive sulphide deposit. Preliminary magnetic susceptibility measurements on the massive sulphide orebodies were also made. 


\section{Geological framework}

The Draa Sfar mine is located at the southern limit of the Jebilet massif, in the southern part of the West Moroccan Meseta (Fig. 1). The Jebilet massif, extending $170 \mathrm{~km}$ EW and $40 \mathrm{NS}$, is interpreted to be an intracontinental, Devonian-Carboniferous rift-basin that formed during a period of extension during rifting of continental crust in a back-arc geodynamic environment ([Huvelin, 1977] and [Aarab and Beauchamp, 1987]). The Jebilet massif consists of three lithotectonic domains, the Western, Central, and Eastern Domains (Fig. 1b), which are separated by major shear zones ([Huvelin, 1977] and [Lagarde and Choukroune, 1982]). The Western Domain consists of Cambrian and Ordovician rocks, whereas the Central domain consists of metamorphosed and deformed upper Visean (350 to $340 \mathrm{Ma}$ ) rocks. The Eastern Domain is also comprised of Visean rocks, but is covered by nappes that contain strata ranging from Ordovician to early Carboniferous in age.

The Central Jebilet Domain (CJD) consists of a thick succession of argillites and carbonaceous argillites (up to $1.5 \mathrm{~km}$ thick), representing the lower part of the succession. These are overlain by Carboniferous, carbonaceous argillites and limestones $(<100 \mathrm{~m})$ that define the top of an interpreted basin-fill succession (Bordonaro, 1983). The argillites of the CJD are interpreted by Beauchamp et al. (1991) to have been deposited in an anoxic, shallower water environment. The end of the Carboniferous is characterized by the development of the Mesetian basin where intense volcanic and volcano-sedimentary activity ([Bordonaro, 1983], [Aarab and Beauchamp, 1987] and [Bernard et al., 1988]) is characterized by three types of magmatism: (1) bimodal, subvolcanic rift-related tholeiitic gabbro and minor rhyolite and rhyodacite flows; (2) syntectonic calc-alkaline granite intrusions and (3) post-tectonic, microdiorite dykes and sills ([Huvelin, 1977], [Bernard et al., 1988] and [Essaifi et al., 2004]).

Deformation in the CJD is marked by the Hercynian east-west $\mathrm{D}_{1}$ shortening that is responsible for the orientation of the north-striking, transposed strata, development of the main regional $\mathrm{S}_{1}$ schistosity (striking NS and subvertical), regional folds that trend $030^{\circ}$, and the emplacement of syntectonic granites. The $\mathrm{D}_{1}$ deformation is associated with low-grade regional metamorphism, typified by a quartz-muscovite-chlorite assemblage. D1 shortening was followed by an $\mathrm{N}-\mathrm{S} \mathrm{D}_{2}$ shortening $\left(\mathrm{S}_{2}\right.$ crenulation cleavage) and late brittle deformation ([Huvelin, 1977], [Bordonaro, 1983] and [Bernard et al., 1988]).

Several massive sulphide deposits, including Draa Sfar, are hosted by the volcanosedimentary succession within the CJD (Fig. 1b). The deposits are stratiform, characterized by a sulphide mineralogy dominated by pyrrhotite (70 to $95 \%$ of sulphide minerals) and range from Zn-rich polymetallic mineralization (e.g., Koudiat Aicha - $4.5 \mathrm{Mt}$ grading $2.7 \mathrm{wt} . \% \mathrm{Zn}$, 1.2 wt.\% $\mathrm{Pb}$ and 0.6 wt.\% Cu, Draa Sfar - $10 \mathrm{Mt}$ grading 5.3 wt.\% $\mathrm{Zn}, 2$ wt.\% $\mathrm{Pb}$ and $0.3 \mathrm{wt} . \% \mathrm{Cu}$ ), to low-grade sulphide deposits (e.g., Kettara; $30 \mathrm{Mt}$ of pyrrhotite at $0.7 \mathrm{wt} . \%$ $\mathrm{Cu}$ ) (Table 1). The sulphide deposits are pretectonic as they are affected by the $\mathrm{S}_{1}$ schistosity and generally occur as folded and dislocated sheet-like orebodies ([Bordonaro, 1983] and [Bernard et al., 1988]). 


\section{Geology of the Draa Sfar Deposit}

A thorough description of the lithofacies, structure and stratigraphy of the Draa Sfar deposit is provided by Belkabir et al. (2007-this issue) and only a summary is provided below. The Draa Sfar deposit occurs within a dominantly sedimentary succession characteristic of the lower CJD strata. The orebodies occur in the upper part of the Sarhlef series and are underlain by more than $500 \mathrm{~m}$ of argillite and carbonaceous argillite with intercalated siltstone and a subordinate, but locally dominant coherent rhyolite and volcaniclastic lithofacies (Fig. 2 and Fig. 3). The Draa Sfar deposit is conformably overlain by a thinly bedded carbonaceous argillite and intercalated siltstone that is intruded by a thick gabbro sill. The host rocks strike NNE-SSW, and are flattened parallel to the $\mathrm{S}_{1}$ foliation (Fig. 2). Within the least-deformed volcanic and sedimentary rocks, younging directions were determined from primary structures (crossbedding, grading, synsedimentary loading structures), and these consistently indicate that the strata immediately above and below the deposit are overturned and young to the west (Fig. 2). However, on a slightly larger scale, facies variations (e.g., coherent rhyolite to volcaniclastic facies) and facing directions indicate that the rocks are folded about a northtrending $F_{1}$ anticline that places the Draa Sfar deposit on the west limb of this fold (Fig. 2 and Fig. 3). The rocks contain assemblages of chlorite, muscovite, quartz, albite, and rare oligoclase-orthoclase indicative of a greenschist metamorphic grade.

\subsection{The Draa Sfar deposit: morphology and characteristics}

The Draa Sfar deposit contains $10 \mathrm{Mt}$ of ore grading 5.3 wt.\% $\mathrm{Zn}, 2$ wt.\% $\mathrm{Pb}, 0.3$ wt.\% Cu, which places it in the of $\mathrm{Zn}-\mathrm{Pb}-\mathrm{Cu}$ group of volcanogenic massive sulphide (VMS) deposits, close to the $\mathrm{Zn}-\mathrm{Pb}$ tie-line of Franklin et al. (1981). However, the dominance of pelitic sedimentary rocks in both the stratigraphic hanging wall and footwall places the Draa Sfar deposit in the pelitic subgroup of the siliciclastic-felsic type of Franklin et al. (2005), which also includes VMS deposit of the Iberian Pyrite Belt, Spain and Portugal, and the Bathurst mining Camp, Canada.

The Draa Sfar deposit strikes N to NNE and extends for more than $1.7 \mathrm{~km}$. The deposit is overturned and dips steeply to the east and faces west. It contains two orebodies: a southern, zinc-rich orebody called Tazakourt, and a northern more copper-rich orebody called Sidi M'Barek that is dismembered by cross-faults (Fig. 2). At the surface the two orebodies are separated by the Tensift River, but there is no structural discontinuity between the orebodies. The two orebodies consist of $\mathrm{Fe}-\mathrm{Zn}-\mathrm{Cu}-\mathrm{Pb}$ lenses of massive sulphides that are predominantly composed of pyrrhotite.

Tazakourt consists of one lens of massive sulphide that extends N-S for more than $1 \mathrm{~km}$. The footwall to Tazakourt consists of felsic volcanic rocks, argillite and carbonaceous argillite, interbedded with siltstone, whereas the hanging wall consists of carbonaceous argillite and interbedded siltstone (Fig. 3 and Fig. 4). The massive sulphides are hosted by argillite and interbedded siltstone (Fig. 4 and Fig. 5). The orebody has been delineated between the $-50 \mathrm{~m}$ and $-900 \mathrm{~m}$ levels, and remains open at depth. The Tazakourt orebody, which lies stratigraphically above a coherent rhyolite, is the main Zn-rich massive sulphide lens with an average grade of 8 to 9 wt.\% $\mathrm{Zn}, 0.3 \mathrm{wt} . \% \mathrm{Cu}$ and 1 to $2 \mathrm{wt. \%} \mathrm{Pb}$ (Fig. 2). Base metal zoning $(\mathrm{Zn}$ relative to $\mathrm{Cu}$ ) in this body indicates a trend to $\mathrm{Cu}$-enrichment in the south and $\mathrm{Zn}$ enrichment to the north. Tazakourt is well delimited by drill-holes and represents the main ore lens at Draa Sfar. 
The Sidi M'Barek orebody consists of two massive sulphides lenses that are also hosted by the argillite-siltstone lithofacies (Fig. 3 and Fig. 5). The western or upper Zn-rich lens (6 to 7 wt. $\% \mathrm{Zn}$ and $\sim 0.3 \mathrm{wt} . \% \mathrm{Cu},<1 \mathrm{wt} . \% \mathrm{~Pb}$ ) is interpreted to be a continuation of the Tazakourt ore lens. The eastern or lower lens is more Cu-rich $(2$ to 3 wt.\% $\mathrm{Cu},<1 \mathrm{wt} . \% \mathrm{Zn}$, $<1 \mathrm{wt} . \% \mathrm{~Pb}$ and $\sim 600$ to $700 \mathrm{ppm} \mathrm{Co}$ ). Sidi M'Barek is only exposed in drill cores and has not yet been delineated. Drilling indicates that both the upper and lower lenses are vertically continuous but are discontinuous along strike (less than $70 \mathrm{~m}$ in along-strike continuity).

The pyrrhotite-rich orebodies occur on the east limb of a large anticline that plunges towards north ([Bernard et al., 1988] and [Belkabir et al., 2007-this issue]) (Fig. 2). The Tazakourt orebody is commonly boudinaged with thicknesses that range from 0.2 to $20 \mathrm{~m}$. Such variations in thickness are observed in plan and section from surface to the $-800 \mathrm{~m}$ level and impart a "pinch and swell geometry" to the orebody (Fig. 3 and Fig. 4). Inclusions of chloritized argillite-siltstone occur within the massive sulphide lens and locally form piercement structures within massive pyrrhotite orebody (Belkabir et al., 2007-this issue). The development of boudins and piercement structures reflects the difference in competency between the more competent pyrrhotite-rich ore lens and the less competent chloritized and schistose sedimentary rocks. The contact between the sulphide lens and the hanging wall carbonaceous argillites is an $\mathrm{N} 10-70^{\circ} \mathrm{E}$ trending fault defined by tectonic breccias and fault gouge. The thickest sections of massive sulphide contain tectonic breccia and cm-scale $(0.2$ to $1 \mathrm{~m}$ long) lozenges of chloritized sedimentary rocks now altered to a talc-chlorite-carbonate assemblage or massive chloritized argillite that are cross-cut by post- $\mathrm{S}_{1}$, barren pyrite veinlets (Fig. 6a,b).

Where the ore lens is thin ( 1 to $5 \mathrm{~m}$ ) the sulphides are typically banded and may grade into zones of disseminated sulphides. Within the massive sulphide lens primary textures are typically not preserved. The footwall contact of the ore lens is often marked by pyrrhotite veinlets in chloritized argillite (Fig. 6h), by highly deformed massive bodies of black chlorite that is interpreted to replace argillite, or by pyrrhotite-chalcopyrite nodules disseminated within argillites (Fig. 6i; Belkabir et al., 2007-this issue).

A feeder or stockwork sulphide zone has not been identified at Draa Sfar, but the lower or eastern $\mathrm{Cu}$-rich lens at Sidi M'Barek has a higher copper content and contains bismuth selenides that are characteristic of sulphide stockwork zones that underlie VMS deposits of the Iberian Pyrite Belt ([Marcoux et al., 1996] and [Leistel et al., 1998]). Bismuth selenides suggest that the lower, Cu-rich, ore lens at Sidi M'Barek may represent the upper part of a stockwork zone for the Draa Sfar ore deposit that has been strongly transposed by deformation. The more $\mathrm{Cu}$-rich southern portion of the Tazakourt orebody may suggest proximity to another, yet undiscovered, stockwork zone?

Intense surface oxidation zones are known around Draa Sfar. At Tazakourt, there are surface oxidation zones related spatially to faults and fractures that intersect the massive sulphide lens but these are not well developed. However, at Sidi M'Barek a well-developed gossan extends to a depth of $20 \mathrm{~m}$. 


\subsection{Mineralogy and textures of sulphides lenses}

The Draa Sfar orebodies consist dominantly of pyrrhotite (70 to 95 vol.\% of sulphides, but commonly up to 90 to $95 \mathrm{vol} \%$ in $\mathrm{Zn}$ and $\mathrm{Cu}$-depleted zones), with lesser sphalerite (1 to 10 vol.\%), galena ( 0.5 to 5 vol.\%) and chalcopyrite ( 1 to 5 vol.\%, with the exception of the $\mathrm{Cu}$-rich lower lens at Sidi M'Barek where chalcopyrite content reaches 15 vol.\%), and with local concentrations of deformed pyrite ( 2 to 3 vol.\% of total sulphides). Faint, but recognizable tectonic banding with massive sulphide reflects variations in the proportions of the different sulphide minerals. Accessory minerals include chlorite (clinochlore), siderite, talc, quartz, muscovite, and commonly ilmenite.

Pyrrhotite is always the dominant sulphide (Fig. 6 and Fig. 7). It is not nickel bearing (Ni contents below $150 \mathrm{ppm}$ based on EPMA analyses) and pentlandite has only been observed rarely as minute flames $(30 \mu \mathrm{m} \times 3-5 \mu \mathrm{m})$ in pyrrhotite from the Tazakourt orebody. EPMA indicate that pyrrhotite has a very homogeneous composition throughout the entire deposit, with a structural formula close to $\mathrm{Fe}_{7} \mathrm{~S}_{8}$ and $\mathrm{X}_{\mathrm{FeS}}$ close to 0.93 (Table 2). Three trace elements have been detected in the pyrrhotite: arsenic and bismuth, that occurs in pyrrhotite from all the sulphide lenses, but in various amounts (average grades of 600 and $500 \mathrm{ppm}$, respectively), and cobalt which is restricted to pyrrhotite in the northern, $\mathrm{Cu}$-rich lower lens at Sidi M'Barek (900 ppm).

Sphalerite is the next most common sulphide and it can be the dominant sulphide within millimetre-wide bands (Fig. 7a-c). It is always associated with pyrrhotite. EPMA analyses indicate a uniform iron content for sphalerite that ranges from 6.0 to $8.2 \mathrm{wt}$ \% $\mathrm{Fe}$ (9.4 to 12.8 , mean 11.4 to mol\% FeS) throughout the deposit (Table 2, Fig. 8). Cadmium is present, but in highly variable amounts (mean $500 \mathrm{ppm}$ ). Copper is also highly variable (0 to $2500 \mathrm{ppm}$ ) and higher values may be due to minute inclusions of chalcopyrite. Silver has not been detected and chalcopyrite disease within sphalerite has not been observed.

Galena occurs preferentially with sphalerite but is less abundant and Ag-free (Fig. 7b). Inclusions of silver minerals have not been observed. Chalcopyrite is of low abundance except within the lower or eastern lens at Sidi M'Barek, where it locally represents 10 to 15 vol.\% of the ore and is the most abundant sulphide after pyrrhotite (Fig. 6 and Fig. 9).

Pyrite and marcasite are rare ( $<1$ vol. $\%$ of sulphides) at Tazakourt but are more common at Sidi M'Barek (2 to 3 vol.\%). Pyrite shows two associations; 1) the first association is least common (Fig. 6 and Fig. 7), synchronous with pyrrhotite, and displays framboidal to ovoid textures that are usually considered as indicators of a primary, sedimentary origin; 2) the second association is much more common and is interpreted to be secondary, a product of the oxidative alteration of pyrrhotite (Fig. 6 and Fig. 7). It occurs as inclusions, sometimes a cm in size, within pyrrhotite, where it is associated with secondary magnetite and marcasite. Typically, the abundance of secondary pyrite is associated with carbonate veins that have a marcasite rim (Fig. 7f). The transformation of pyrrhotite to pyrite results in a volume loss and zones with secondary pyrite often appear vuggy and porous. Secondary pyrite also occurs as thin bands parallel to pyrrhotite-rich bands.

Arsenopyrite is the most common of the minor minerals. It is interpreted to have formed early as it always appears as fragmented or corroded crystals within other sulphides (Fig. 7a, c). Arsenopyrite is absent in the lower $\mathrm{Cu}$-rich lens at Sidi M'Barek, although it is fairly common 
in zinc-rich lens at Tazakourt. However, Co-bearing arsenopyrite crystals of less than $0.1 \mathrm{~mm}$ in size have been reported from Sidi M'Barek (Barrakad et al., 1977).

EPMA analyses indicate that, regardless of grain size, arsenopyrite is As-rich (31.2 to 34.3 atom. $\%$ As and an average 33.26 atom.\% As) (Table 2). Cobalt and selenium are present but in variable amounts: 0 to $0.47 \%$ (average $500 \mathrm{ppm}$ ) and 0 to $0.34 \%$ (average $700 \mathrm{ppm}$ ) respectively, but antimony and nickel were not detected.

$\mathrm{A} \mathrm{Bi}-\mathrm{Se}$ association was recognized in samples from the lower $\mathrm{Cu}$-rich lens at Sidi M'Barek. Here, small $(15$ to $30 \mu \mathrm{m})$ inclusions of laitakarite, $\mathrm{Bi}_{4}(\mathrm{Se}, \mathrm{S})_{3}$, and native bismuth were observed within chalcopyrite (Table 2). However, small $(20 \mu \mathrm{m})$ paraguanajuatite $\left(\mathrm{Bi}_{2} \mathrm{~S}_{3}\right)$, cobaltite (CoAsS) and mackinawite $(\mathrm{FeS})$ inclusions reported from this orebody, and electrum, cassiterite and bismuthinite $\left(\mathrm{Bi}_{2} \mathrm{~S}_{3}\right)$ reported from Tazakourt, by Barrakad et al. (1977), were not observed in our samples.

Penetrative deformation and regional metamorphism have destroyed evidence of primary features within the sulphide lenses and obscured the recognition of multiple stages of mineralization with distinct assemblages. The exception to this is the obviously secondary association of pyrite-marcasite-magnetite, which is clearly late and related to a later fracturing and veining of the massive sulphide lenses.

The Draa Sfar ore mineralogy is similar to, but even more pyrrhotite-rich, than that of the Hajar deposit ([Ed Debi et al., 1998] and [Hibti et al., 1999]). This dominance of pyrrhotite is typical of Moroccan VMS deposits and is discussed below.

\subsection{Textures and deformation of the ore}

The ore textures at Draa Sfar are a product of several deformation events that have strongly modified the original textures and mineral assemblages. Regional metamorphism has caused an intense recrystallization of the sulphides, particularly in the Cu-rich lens of Sidi M'Barek (Fig. 6a). Pyrrhotite grains are equigranular, sub-mm in size, contiguous, with a polygonal texture and $120^{\circ} \mathrm{C}$ angles, features that are indicative of metamorphic recrystallization (Fig. 9a, b), but which can form under low-grade metamorphic conditions (Gilligan and Marshall, 1987). Coexisting chalcopyrite occurs interstitial to pyrrhotite where it forms large anhedral, undeformed grains that display linear twinning. Where aligned, the chalcopyrite grains define a transposed $S_{1}$ foliation (Fig. 6a).

Following metamorphic recrystallization, the Draa Sfar deposit has undergone subsequent deformation events that have affected most of the ore lenses. There is abundant evidence for a later ductile deformation event responsible for the development of a mylonitic microfabric and tectonic banding within massive sulphide (Fig. 6 and Fig. 9). This mylonitic microfabric is characterized by the development of $\mathrm{S}_{1}$ and $\mathrm{S}_{2}$ foliations ( $\mathrm{C}, \mathrm{C}^{\prime}$ and $\mathrm{S}$ planes), marked by stretching and flow of pyrrhotite and chalcopyrite around more rigid nuclei composed of gangue and sphalerite, and by the comminution of pyrrhotite grains with development of subgrains, dislocation planes, pressure lamellae and pressure shadows (Fig. 9d). C planes are spaced and discontinuous, whereas $\mathrm{C}^{\prime}$ planes are located in planes close to the global shear plane. We have also observed boudins and pinch-and-swell structures, including tectonic enclaves of chloritized sedimentary rocks within massive sulphide, piercement structures (Maiden et al., 1986), and isoclinal $\mathrm{D}_{1}$ and $\mathrm{D}_{2}$ folds (Fig. 6d, e) where sphalerite and galena are often concentrated within saddles of microfold hinges. In pressure shadows, and other low 
strain domains, granoblastic polygonal textures with no clear orientation are common. Chalcopyrite, being more ductile than pyrrhotite (Gilligan and Marshall, 1987), shows a more pronounced flow than sphalerite and galena.

The massive sulphide lenses are also affected by several generations of late brittle faults (Fig. 2) that locally displace the main orebody up to $50 \mathrm{~m}$. Carbonate-filled veinlets associated with secondary pyrite and marcasite are very likely related to this later brittle faulting event (Fig. $7 f)$.

\subsection{Magnetic characteristics of the Draa Sfar ore}

A brief study of the magnetic properties of the Draa Sfar orebody was conducted in order to determine the type of pyrrhotite (monoclinic or hexagonal), and its magnetic characteristics. Two types of measurements were taken: 1) absolute magnetic susceptibility and, 2) thermoremnant magnetism, determined by heating the samples to the Curie temperature $\left(700^{\circ} \mathrm{C}\right)$ and then cooling (analyst: Y. Chen ISTO Orléans).

The Draa Sfar ore has an absolute magnetic susceptibility of about $2.10^{-3} \mathrm{SI} / \mathrm{g}$, markedly less than that of ore at Hajar $\left(5.3 .10^{-3} \mathrm{SI} / \mathrm{g}\right)$. Thermoremnant magnetic profiles show a loss of magnetic susceptibility above the Curie temperature of pyrrhotite (about $340^{\circ} \mathrm{C}$ ), which indicates that monoclinic pyrrhotite is the only magnetic mineral within the ore (Fig. 10). The appearance of a broad second peak in magnetic susceptibility centred around $560^{\circ} \mathrm{C}$ suggests the appearance of hematite by partial oxidation of pyrrhotite. Partial oxidation of pyrrhotite explains the intensity decrease of the first pyrrhotite peak on the cooling curve.

\section{Lead isotope data and implications}

Except for one sample, taken from the gossan at Sidi M'Barek, all analyzed samples are from the pyrrhotite-rich, polymetallic massive sulphide orebodies at Tazakourt and Sidi M'Barek and were collected from drill core or underground workings (Table 3). The lead content of the massive sulphide samples is high, ranging from $329 \mathrm{ppm}$ to more than $4 \%$, indicating their variable galena content and corrections for in situ radiogenic enrichment are negligible $(\mu$ ratio ranging from 0 to 0.79 ).

Analytical procedures are summarized herein. Between 10 and $20 \mathrm{mg}$ of sulphide powder was dissolved in $7 \mathrm{~N}^{-H_{2}}$. The residue was taken up in $1 \mathrm{~N} \mathrm{HBr}$ for $\mathrm{Pb}$ chemistry. $\mathrm{Pb}$ was separated in Bio-Rad 10-ml polyethylene columns and Dowex AG1-8X anion resin, using 1N HBR to elute other elements and $6 \mathrm{~N} \mathrm{HCl}$ to elute $\mathrm{Pb}$. Total procedural blanks for $\mathrm{Pb}$ are $<250$ pg. Samples were loaded onto single Re filaments with $\mathrm{H}_{3} \mathrm{PO}_{4}$ and silica gel, and were run at filament temperatures of 1175 to $1225^{\circ} \mathrm{C}$. Analysis of USGS Standard BCR-1 yields $\mathrm{Pb}=13.56 \mathrm{ppm}, \mathrm{U}=1.70 \mathrm{ppm}, \mathrm{Th}=5.86 \mathrm{ppm},{ }^{206} \mathrm{~Pb} /{ }^{204} \mathrm{~Pb}=18.818,{ }^{207} \mathrm{~Pb} /{ }^{204} \mathrm{~Pb}=15.633$, and ${ }^{208} \mathrm{~Pb} /{ }^{204} \mathrm{~Pb}=38.633$ (average of 2 runs, see Tatsumoto et al., 1972). All mass spectrometer runs were corrected for fractionation using NIST SRM981. The average ratios measured for SRM981 on the new Triton Mass spectrometer are ${ }^{206} \mathrm{~Pb} /{ }^{204} \mathrm{~Pb}=16.892 \pm .010$, ${ }^{207} \mathrm{~Pb} /{ }^{204} \mathrm{~Pb}=15.432 \pm .013$, and ${ }^{208} \mathrm{~Pb} /{ }^{204} \mathrm{~Pb}=36.512 \pm .038$ (2 S.D.), based on 15 runs between May 2005 and January 2006. The fractionation correction, based on the values of Todt et al., (1984), is $+0.13 \% / \mathrm{amu}$.

The lead isotopic compositions of the samples range from 18.27 to 19.54 for ${ }^{206} \mathrm{~Pb} /{ }^{204} \mathrm{~Pb}$ (Table 3, Fig. 11). Samples with least radiogenic signatures (near $18.30{ }^{206} \mathrm{~Pb} /{ }^{204} \mathrm{~Pb}$ ) are from 
the more Zn-rich Tazakourt orebody and the upper, Zn-rich sulphide lens at Sidi M'Barek, whereas the most radiogenic samples $\left({ }^{206} \mathrm{~Pb} /{ }^{204} \mathrm{~Pb}=18.50\right.$ to 19.01$)$ are from the more $\mathrm{Cu}$ rich, lower sulphide lens at Sidi M'Barek. The sample taken from the Sidi M'Barek gossan also has a radiogenic signature $\left({ }^{206} \mathrm{~Pb} /{ }^{204} \mathrm{~Pb}=18.84\right)$ that suggests that this gossan developed within a more $\mathrm{Cu}$-rich sulphide lens, an interpretation supported by its higher copper grade. The anomalously radiogenic sample $\left({ }^{206} \mathrm{~Pb} /{ }^{204} \mathrm{~Pb}=19.54\right)$ was taken from a late quartz-pyrite vein; for this single pyritic sample, in situ radiogenic enrichment likely occurred (Table 3).

The lead isotope compositions of all data define a mixing trend (Fig. 11). Based on their lead isotopic composition, the Draa Sfar massive sulphide orebodies record the imprint of two different hydrothermal fluids. The first is characterized by a lower radiogenic lead content $\left({ }^{206} \mathrm{~Pb} /{ }^{204} \mathrm{~Pb}\right.$ ratio of 18.28 to 18.30$)$ and this fluid formed the more $\mathrm{Zn}$-rich sulphide lenses at Tazakourt and Sidi M'Barek. The second fluid contained more radiogenic lead $\left({ }^{206} \mathrm{~Pb} /{ }^{204} \mathrm{~Pb}\right.$ ratio of 19.01) and formed the lower, Cu-rich lens at Sidi M'Barek. This second more radiogenic fluid is interpreted to have overprinted the upper, more Zn-rich Sidi M'Barek sulphide lens resulting in intermediate $\mathrm{Pb}$ isotopic compositions $\left(18.58\right.$ to $18.84{ }^{206} \mathrm{~Pb} /{ }^{204} \mathrm{~Pb}$ ratio). The sample with the highest ${ }^{206} \mathrm{~Pb} /{ }^{204} \mathrm{~Pb}$ ratio (18.77) from the Sidi M'Barek upper lens is interpreted to be the most influenced by the more radiogenic hydrothermal fluid, although chalcopyrite is not observed in this sample. The Draa Sfar lead isotopic compositions plotted on the growth curve of Stacey and Kramers (1975) are consistent with a continental crustal source for the lead, and by inference the other metals $(\mathrm{Zn}, \mathrm{Cu}, \mathrm{Fe})$ without a perceptible mantle contribution.

The variation in the lead isotopic composition of the Draa Sfar deposit is most similar to that of the Miocene Kuroko VMS deposits, in which the black, Zn-rich ore and the yellow, $\mathrm{Cu}-$ ore have significantly different $\mathrm{Pb}$ isotopic compositions within each ore deposit ([Sato, 1975] and [Fehn et al., 1983]). This variability in lead isotopic composition between ore types at Draa Sfar is distinctly different from VMS deposits of the Iberian Pyrite Belt, where isotopic compositions are clustered at both the deposit, and belt scale (Marcoux, 1998).

The magnitude of the variation in lead isotopic compositions at Draa Sfar is significantly larger than that of the Miocene Kuroko VMS deposits (about 0.73 versus 0.10 for ${ }^{206} \mathrm{~Pb} /{ }^{204} \mathrm{~Pb}$ ratios). In the Kuroko deposits, the differences in isotopic composition between black and yellow ores are interpreted to reflect a shift in the proportion of lead contributed from the same sources (Fehn et al., 1983); however, we consider that such a large variation at Draa Sfar indicates the contribution of lead from different sources. Although lead isotopic data for the different host rock types that constitute the regional stratigraphy are not available, the least radiogenic signature $\left({ }^{206} \mathrm{~Pb} /{ }^{204} \mathrm{~Pb}=18.28\right)$ is similar to that for Visean igneous rocks of the Iberian Pyrite Belt that have been corrected for $U$ decay. This suggests a major, if not unique, contribution of volcanic rocks as a source of metal (Marcoux, 1998). The more radiogenic $\mathrm{Cu}$-ore signature $\left({ }^{206} \mathrm{~Pb} /{ }^{204} \mathrm{~Pb}=19.01\right)$ is close to the Doe and Zartman (1979) upper crust $\mathrm{Pb}$ isotope evolutionary curve. This suggests a crustal sedimentary source and, in particular, a contribution from black shales. The latter is typically highly radiogenic, and is abundant in the lithostratigraphic succession (Sarhlef series) that host the Draa Sfar VMS deposit.

The nearby Hajar VMS has a different, less radiogenic isotopic composition $\left({ }^{206} \mathrm{~Pb} /{ }^{204} \mathrm{~Pb}=18.17\right)$, close to VMS deposits of the Iberian Pyrite Belt (average of 18.18 for ${ }^{206} \mathrm{~Pb} /{ }^{204} \mathrm{~Pb}$ ratios). Such a difference between the lead isotopic composition of the sulphide ores at Hajar and Draa Sfar may reflect differences in the metal source and (or) the age of the deposits. However, as the two ore deposits are of Visean age, this alone cannot explain the 
difference in lead isotopic compositions. In spite of similar mineralogical, petrologic and chronological attributes, the pyrrhotite-rich sulphide ores at Hajar and Draa Sfar may differ in their lead and metal sources.

\section{Ar-Ar dating}

Two samples (DS 57 and DSF3G), of polycrystalline sericite and strongly sericitized plagioclase respectively, were analysed with a ${ }^{39} \mathrm{Ar}-{ }^{40} \mathrm{Ar}$ laser probe $\left(\mathrm{CO}_{2} \mathrm{Synrad}^{\circledR}\right)$. Grains of the samples were handpicked under a binocular microscope from crushed rocks $(0.3$ to $2 \mathrm{~mm}$ fraction). Selected grains were wrapped in A1 foil to form packets $(11 \mathrm{~mm} \times 11 \mathrm{~mm} \times 0.5 \mathrm{~mm})$. These packets were stacked up to form a pile, within which packets of flux monitors were inserted every 10 samples. The stack, put in an irradiation can, was irradiated at the McMaster reactor (Hamilton, Canada). The irradiation standard was the sanidine TCR-2 (28.34 Ma according to Renne et al., 1998). The sample arrangement allowed us to monitor the flux gradient with a precision of $\pm 0.2 \%$.

The step-heating experimental procedure is described in detail in (Ruffet et al., 1995) and (Ruffet et al., 1997). Blanks are performed routinely each first or third run, and are subtracted from the subsequent sample gas fractions. Analyses are performed on a Map $215^{\circledR}$ mass spectrometer. To define a plateau age, a minimum of three consecutive steps is required, corresponding to a minimum of $70 \%$ of the total ${ }^{39} \mathrm{Ar}_{\mathrm{K}}$ released, and the individual fraction ages should agree to within $1 \sigma$ or $2 \sigma$ with the integrated age of the plateau segment. All discussed ${ }^{39} \mathrm{Ar}-{ }^{40} \mathrm{Ar}$ results are displayed at the $1 \sigma$ level. Pseudo-plateau ages, with less than $70 \%$ of ${ }^{39} \mathrm{Ar}_{\mathrm{K}}$ released, can also be defined (Table 4).

The two samples display concordant ( $1 \sigma$ level) plateau and pseudo-plateau ages at $c a .331 \mathrm{Ma}$ with very distinct age spectrum shapes (Fig. 12). Sample DSF3G displays a flat age spectrum over $90 \%$ of total ${ }^{39} \mathrm{Ar}_{\mathrm{K}}$ degassing with an increase from the low to the high temperature steps of the measured ${ }^{37} \mathrm{Ar}_{\mathrm{Ca}}{ }^{39} \mathrm{Ar}_{\mathrm{K}}$ ratios, up to $c a$. 100. The corresponding calculated high $\mathrm{CaO} / \mathrm{K}_{2} \mathrm{O}$ ratios $\left(\mathrm{Ca0} / \mathrm{K}_{2} \mathrm{O}={ }^{37} \mathrm{Ar}_{\mathrm{Ca}}{ }^{39} \mathrm{Ar}_{\mathrm{K}} \times 2.179\right.$; Deckart et al., 1997), from ca. 20 up to $c a$. 210, and the low measured ${ }^{39} \mathrm{Ar}_{\mathrm{K}}$ values suggest that the analysed fragment is $\mathrm{Ca}$-rich/K-poor, and mainly composed of plagioclase.

The other sample DS57 yields a much more disturbed age spectrum, with globally a saddle shape for the last $80 \%$ of ${ }^{39} \mathrm{Ar}_{\mathrm{K}}$ degassing, corresponding to a saddle shape of the ${ }^{37} \mathrm{Ar}_{\mathrm{Ca}}{ }^{39} \mathrm{Ar}_{\mathrm{K}}$ spectrum. Excepting the three last steps, the measured ${ }^{37} \mathrm{Ar}_{\mathrm{Ca}}{ }^{39} \mathrm{Ar}_{\mathrm{K}}$ ratios are 2 to 3 orders of magnitude lower than for previous sample and are evidence for degassing of a K-rich phase. The correspondence between the ${ }^{37} \mathrm{Ar}_{\mathrm{Ca}}{ }^{39} \mathrm{Ar}_{\mathrm{K}}$ saddle minimum and the pseudo-plateau age displayed by age spectrum $(330.8 \pm 1.1 \mathrm{Ma})$ suggests that degassing of this K-rich phase, probably sericite, is preponderant in this temperature domain.

Despite similar plateau and pseudo-plateau ages, the two analysed samples show very distinct ${ }^{37} \mathrm{Ar}_{\mathrm{Ca}}{ }^{39} \mathrm{Ar}_{\mathrm{K}}$ spectra which characterize a Ca-rich and a K-rich phase, respectively. The age of the sericite must be younger or equal to the age of the plagioclase. This appears to be the case but what is the significance of the age indicated by sample DSF3G? Two possibilities exist: 1) if the $331.7 \pm 7.9 \mathrm{Ma}$ age is the age of the plagioclase, then it dates volcanism and suggests that sericitization, a product of VMS hydrothermal alteration, was sub-synchronous with rhyolite emplacement; and 2) if the $331.7 \pm 7.9 \mathrm{Ma}$ age is the age of sericite present within 
plagioclase then this age reflects the age of VMS alteration and not necessarily the age of the rhyolite (or of volcanism).

Based on the Ar-Ar ages, we propose that the sericite, a product of the VMS hydrothermal system responsible for sericitization and the formation of the Draa Sfar deposit, has an age of ca. $331 \mathrm{Ma}$. This age is probably contemporaneous with or close to (slightly younger) the age of rhyolite emplacement and volcanism.

\section{Discussion: a genetic model}

Estimating the temperature of formation for such a highly deformed, recrystallized and annealed massive sulphide deposit such as Draa Sfar is extremely difficult. The possible depositional equilibrium of various sulphides has been so strongly disturbed by metamorphism (for which no pressure range can be estimated) that experimental curves for the Fe-Zn-As-S system (Scott, 1983) or the Fe-content of sphalerite and pyrrhotite cannot be used as geothermometers. The chlorite geothermometer (Cathelineau and Nieva, 1985) indicates temperatures ranging from $276{ }^{\circ} \mathrm{C}$ to $346{ }^{\circ} \mathrm{C}$ (hydrothermal clinochlore associated with the massive sulphides, Belkabir et al., 2007-this issue). Within this temperature range, pyrrhotite and sphalerite compositions (about 11 to $12 \mathrm{~mol} \% \mathrm{FeS}$ for the latter) indicate an $f \mathrm{~S}_{2}$ of $10^{-10}-10^{-11}$ ([Kissin and Scott, 1982] and [Scott, 1983]), which is in good agreement with the presence of chalcopyrite and the absence of pyrite and löllingite. Considering all of the above, it seems reasonable to propose that the Draa Sfar ore deposit formed under thermal conditions considered "normal" for Palaeozoic massive sulphides orebodies, i.e., with a $\mathrm{pH}=4, \mathrm{NaCl}=1 \mathrm{~m}, a \mathrm{H}_{2} \mathrm{~S}=10^{-3}, \mathrm{fO}_{2}=10^{-35}$ atm, and $\mathrm{SO}_{4}{ }^{2-} / \mathrm{H}_{2} \mathrm{~S}=10^{-1}$ within a temperature range of $250^{\circ}$ to $300^{\circ} \mathrm{C}$ (Large, 1992).

The abundance of pyrrhotite is a conspicuous feature of the Draa Sfar deposit and, in general, of all the Hercynian VMS deposits in the Jebilet and Guemassa terranes. A notable exception is the Lachach deposit, which contains abundant pyrite (E. Marcoux, unpublished data). The origin of the pyrrhotite (i.e. primary or metamorphic) is uncertain (e.g., Hajar; Ed Debi et al., 1998).

At Draa Sfar, all observations suggest a primary origin for the pyrrhotite. The metamorphic transformation of pyrrhotite to pyrite requires a high temperature that would also have resulted in the development of calc-silicate minerals such as wollastonite, hedenbergite or andradite, which are unknown or present in only trace amounts at Draa Sfar. The mineral assemblages andradite-pyrrhotite and wollastonite-pyrrhotite are stable above $300{ }^{\circ} \mathrm{C}$ at pressures of $<2 \mathrm{kbar}$ and where $f \mathrm{~S}_{2}$ is less than $10^{-11}$ (Gamble, 1982). The low-grade metamorphic assemblages at Draa Sfar (chlorite and absence of biotite) suggest that the temperatures required to transform pyrrhotite to pyrite by metamorphic desulphidation reactions were not achieved. Relict primary "pyrite" has not been observed. Pyrite occurs as secondary porphyroblasts after pyrrhotite including relicts of pyrrhotite incorporated during growth, and also occurs as late crosscutting veins. Slow metamorphic cooling of pyrrhotite is a process accompanied by little change in the composition of this mineral and any sulphur released is rapidly fixed as pyrite (Vaughan and Craig, 1997). Scarcity of secondary pyrite at Draa Sfar indicates only limited release of sulphur during metamorphism.

The abundance of primary pyrrhotite at Draa Sfar and in other VMS deposits of the Jebilet and Guemassa terranes can be ascribed to several processes. Many pyrrhotite-and magnetitebearing Archean VMS deposits are interpreted to reflect the lower $f \mathrm{O}_{2}\left(10^{-42}\right.$ atm. at $\left.300{ }^{\circ} \mathrm{C}\right)$ 
and $a \mathrm{H}_{2} \mathrm{~S}\left(10^{-3}\right)$ content of the ore fluid ([Large, 1977] and [Large, 1992]). Such sulphur- and oxygen-poor fluids have also been suggested to explain the pyrrhotite (and magnetite)-rich VMS deposits in the highly sedimented, Middle Valley of the modern seafloor (Krasnov et al., 1994). Sharpe and Gemmel (2002) suggested that at $250^{\circ} \mathrm{C}$ pyrrhotite is stable over a wide range of $\mathrm{pH}(2$ to $\sim 7.5)$ and low $f \mathrm{O}_{2}$ conditions, below $10^{-39}$ and $10^{-41}$ for total dissolved sulphur (mostly $\mathrm{H}_{2} \mathrm{~S}$ ) in hydrothermal fluid of $10^{-3} \mathrm{~m}$ and $10^{-2} \mathrm{~m}$, respectively, as an explanation for pyrrhotite formation within the magnetite-rich, Gossan Hill VMS deposit. At lower $\mathrm{S}$ content, the pyrrhotite field drops to very low $f \mathrm{O}_{2}$ values $\left(10^{-42} \mathrm{~atm}\right)$ and the presence of clinochlore restricts the $\mathrm{pH}$ range between 4.3 and 5.3 (Helgeson, 1969 in Large, 1977).

In summary, we believe that very low $\mathrm{fO}_{2}$ conditions are the main reason for the formation of primary pyrrhotite at Draa Sfar, and neither a high temperature nor a low $\mathrm{aH}_{2} \mathrm{~S}$ (below $10^{-3}$ ) is required. The highly anoxic conditions required to stabilize pyrrhotite over pyrite are consistent with the deposition setting and reconstruction of the Draa Sfar deposit, which is interpreted to form within a restricted, sediment-starved, anoxic basin characterized by the deposition of carbonaceous, pelagic sediments along the flank of a rhyolitic flow-dome complex that was buried by pelitic sediments (Belkabir et al., 2007-this issue). Deposition of sulphides likely occurred at and below the seafloor within anoxic and carbonaceous muds as proposed for the Hajar deposit (Leblanc, 1993).

However, between the formation of the initial $\mathrm{Zn}$-rich and subsequent more $\mathrm{Cu}$-rich orebodies the lead isotope data suggest that hydrothermal circulation changed to reflect a different source rock, this source rock may have been richer in copper such as black shales, or the fluid may have had a higher temperature increasing its ability to dissolve and carry copper.

Nevertheless, metamorphism and deformation had a visible and pronounced effect on the pyrrhotite-rich massive sulphides at various scales. The sheet-like form of the orebodies may, in part, be primary but it also certainly reflects accentuation and flattening during deformation. Metamorphism has resulted in sulphide recrystallization and the characteristic development of pyrrhotite with $120^{\circ}$ triple junctions. Ductility contrasts during deformation and metamorphism resulted in the development of shear zones along the contacts of the orebodies with their host sedimentary rocks, the development of boudinaged ore lenses, and the development of shear zones that produced local mylonite zones of within the orebodies. These metamorphic and deformational induced transformations mask primary textures within the orebodies and have modified metal zoning patterns.

\section{Conclusions}

The Draa Sfar deposit is characterized by an abundance of primary pyrrhotite, absence of primary pyrite, and by two $\mathrm{Zn}$-rich and one $\mathrm{Cu}$-rich sulphide orebodies, each with its own lead isotope composition. Draa Sfar is a "classical" VMS deposit generated by metal-bearing, acidic hydrothermal fluids derived through the interaction of evolved seawater with sedimentary and lesser volcanic rocks, with convection driven by a high geothermal gradient associated with rifting and localized volcanism $c a$. 331 Ma. A multistage model including; i) precipitation of $\mathrm{Zn}$-rich polymetallic sulphides and ii) later deposition of more $\mathrm{Cu}$-rich ore at higher temperature, also seems valid for Draa Sfar ([Large, 1977] and [Franklin et al., 2005]).

VMS deposits of the Jebilet and Guemassa terranes (Fig. 1a, b) have been compared to those of the Iberian Pyritic Belt (IPB) deposits ([Bernard et al., 1988], [Leistel et al., 1998] and 
[Lescuyer et al., 1998]). These authors have stressed the similarities between the two districts in term of age, volcanosedimentary host rocks, and paleogeodynamic setting. The Iberian and Moroccan terranes lie in an epicontinental domain of the outer zone of the Hercynian belt and the VMS deposits formed within an environment that has a high sedimentary component, one that is more siliciclastic in the IPB and more pelagic in the Jebilet and Guemassa areas (Lescuyer et al., 1998). Other differences between the IPB and Jebilet VMS deposits include the mineralogy of the ore, with the predominance of pyrrhotite and scarcity of lead in the Jebilet and Guemassa deposits, in contrast to the pyrite-rich and more polymetallic VMS deposits of the IPB. These differences in mineralogy are interpreted to reflect differences in the depositional environment of the sulphide ores, and the differences in lead isotopic characteristics reflect differences in source rocks.

In spite of the diachronous emplacement between the IPB deposits (late Devonian to Visean) and Moroccan deposits (Visean), it is possible to define a main metalliferous peak around $340 \pm 10 \mathrm{Ma}$ that occurred during rifting, which followed a Devonian compression event (Lescuyer et al., 1998).

\section{Acknowledgements}

This research would not have been possible without the logistical and financial support provided by REMINEX and the Draa Sfar mine. REMINEX exploration staff Solange Brunet, Chief geologist, Lhou Maacha, Director, and S. Rziki mine geologist at Draa Sfar provided valuable insight into the geology of the Draa Sfar mine and made available all maps, plans, sections and assay data. HLG gratefully acknowledges the financial support of an NSERC

discovery grant. Jan Peter and an anonymous reviewer are gratefully thanked for improvement of the manuscript.

\section{References}

Aarab and Beauchamp, 1987 El. Aarab and J. Beauchamp, Le magmatisme carbonifère préorogénique des Jebilet centrales (Maroc). Précisions pétrographiques et sédimentaires. Implications géodynamiques, Comptes Rendus de l'Académie des Sciences Paris (Série II) 304 (1987), pp. 169-175.

Barrakad et al., 1977 A. Barrakad, P. Huvelin, C. Laforêt, S. Perez, F. Permingeat and P. Picot, Minéraux de cobalt, d'étain, de bismuth, de sélénium, d'or et d'argent dans l'amas sulfuré à pyrrhotite de Sidi Embarek (Jebilet), Notes du Service Géologique du Maroc 37 (1977), pp. 129-138.

Beauchamp et al., 1991 J. Beauchamp, A. Izart and A. Piqué, Les bassins d'avant-pays de la chaîne hercynienne au Carbonifère inférieur, Canadian Journal of Earth Sciences 28 (1991), pp. 2024-2041.

Belkabir et al., 2007-this issue Belkabir, A., Gibson, H., Marcoux, E., Lentz, D., Rziki, S., 2007-this issue. Geology and Wall-Rock Alteration at the Hercynian Draa Sfar $\mathrm{Zn}-\mathrm{Pb}-\mathrm{Cu}$ Deposit, Morocco Ore Geology Reviews. 
Bernard et al., 1988 A.J. Bernard, O.W. Maier and A. Mellal, Aperçu sur les amas sulfurés massifs des hercynides marocaines, Mineralium Deposita 23 (1988), pp. 104-144.

Bordonaro, 1983 Bordonaro, M., 1983. Tectonique et petrographie du district à pyrrhotine de Kettara (Paléozoïque des Jebilets, Maroc). Thèse 3ème cycle, Université Louis Pasteur de Strasbourg, 132pp.

Cathelineau and Nieva, 1985 M. Cathelineau and D. Nieva, A chlorite solid solution geothermometer: the Los Azufres (Mexico) geothermal system, Contributions to Mineralogy and Petrology 91 (1985), pp. 235-244.

Deckart et al., 1997 K. Deckart, G. Feraud and H. Bertrand, Age of Jurassic continental tholeiites of French Guyana, Surinam and Guinea: implications for the initial opening of the Central Atlantic ocean, Earth and Planetary Science Letters 150 (1997), pp. 205-220.

Doe and Zartman, 1979 B.R. Doe and R.E. Zartman, Plumbotectonics, the Phanerozoic. In: H.L. Barnes, Editor, Geochemistry of Hydrothermal Ore Deposits, John Wiley and Sons, New York (1979), pp. 22-70.

Ed Debi et al., 1998 A. Ed Debi, A. Saquaque, M. Kersit and A. Chbiti, L'amas sulfuré de Hajar (Guemassa, Maroc), Chronique de la Recherche Minière 531-532 (1998), pp. 45-54.

Essaifi et al., 2004 A. Essaifi, R. Capdevila, S. Fourcade, J-L. Lagarde, M. Ballèvre and C. Marignac, Hydrothermal alteration, fluid flow and volume change in shear zones: the layered mafic-ultramafic Kettara intrusion (Jebilet Massif, Variscan belt, Morocco), Journal of Metamorphic Geology 22 (2004), pp. 25-43.

Fehn et al., 1983 U. Fehn, B.R. Doe and M.H. Delevaux, The distribution of lead isotopes and the origin of Kuroko ore deposits in the Hokuroku district, Japan, Economic Geology Monograph 5 (1983), pp. 488-506.

Franklin et al., 1981 J.M. Franklin, D.F. Sangster and J.W. Lydon, Volcanic associated massive sulfide deposits, Economic Geology 75th Anniversary Volume (1981), pp. 485-627.

Franklin et al., 2005 J.M. Franklin, H.L. Gibson, I.R. Jonasson and A.G. Galley, Volcanogenic massive sulphide deposits, Economic Geology 100th Anniversary Volume (2005), pp. 523-560.

Gamble, 1982 R.P. Gamble, An experimental study of sulfidation reactions involving andradite and hedenbergite, Economic Geology 77 (1982), pp. 784-797.

Gilligan and Marshall, 1987 L.B. Gilligan and B. Marshall, Textural evidence for remobilization in metamorphic environments, Ore Geology Reviews 2 (1987), pp. 205-229.

Helgeson, 1969 H.C. Helgeson, Thermodynamics of hydrothermal systems at elevated temperatures and pressures, American Journal of Sciences 267 (1969), pp. 729-804.

Hibti et al., 1999 M. Hibti, M. Bouabdelli, A. Mouttaqi and J.-P. Sagon, L'effet du métamorphisme sur les minéralisations sulfurées de la province hercynienne (Meseta sud- 
occidentale, Maroc). Exemples des gisements sulfurés de Hajjar et de Kettara, Chronique Recherche Minière 536-537 (1999), pp. 23-37.

Huvelin, 1977 P. Huvelin, Etude géologique et gîtologique du Massif hercynien des Jebilet (Maroc occidental), Notes et mémoires du Service Géologique du Maroc 37 (1977), pp. 7-22.

Kissin and Scott, 1982 S.A. Kissin and S.D. Scott, Phase relations involving pyrrhotite below $350{ }^{\circ} \mathrm{C}$, Economic Geology 77 (1982), pp. 1739-1754.

Krasnov et al., 1994 S. Krasnov, T. Stepanova and M. Stepanov, Chemical composition and formation of a massive sulfide deposits, Middle Valley, northern Juan de Fuca Ridge (site 856), Proceedings of the Ocean Drilling Program. Scientific Results 139 (1994), pp. 353372.

Lagarde and Choukroune, 1982 J.L. Lagarde and P. Choukroune, Cisaillement ductile et granitoïdes syntectoniques, l'exemple du massif hercynien des Jebilet (Maroc), Bulletin de la Société Géologique de France 24 (2) (1982), pp. 299-307.

Large, 1977 R.R. Large, Chemical evolution and zonation of massive sulfide deposits in volcanic terrains, Economic Geology 72 (1977), pp. 549-572.

Large, 1992 R.R. Large, Australian volcanic-hosted massive sulfide deposits: features, styles and genetic models, Economic Geology 87 (1992), pp. 471-510

Leblanc, 1993 M. Leblanc, Amas sulfuré formé par injection des sills dans des sédiments. Exemple d'Hajar -Marrakech, Maroc), Comptes Rendus de l'Académie des Sciences Paris 316 (1993), pp. 499-504

Leistel et al., 1998 J.M. Leistel, E. Marcoux, D. Thiéblemont, C. Quesada, A. Sanchez, G.R. Almodovar, E. Pascual and R. Saez, The volcanic-hosted massive sulphide deposits of the Iberian pyrite belt. Review and preface to the Thematic Issue, Mineralium Deposita 33 (1998), pp. 2-30.

Lescuyer et al., 1998 J.L. Lescuyer, J.M. Leistel, E. Marcoux, J.P. Milési and D. Thiéblemont, Late Devonian-Early Carboniferous peak sulphide mineralization in the Western Hercynides, Mineralium Deposita 33 (1998), pp. 208-220.

Maiden et al., 1986 K.J. Maiden, L.R. Chimimba and T.J. Smalley, Cuspate ore-wallrock interfaces, piercement structures and the localization of some sulphides ores in deformed sulfide deposits, Economic Geology 81 (1986), pp. 1464-1472.

Marcoux, 1998 E. Marcoux, Lead isotope systematics of the giant massive sulphide deposits in the Iberian Pyrite Belt, Mineralium Deposita 33 (1998), pp. 45-58.

Marcoux et al., 1996 E. Marcoux, Y. Moëlo and J.M. Leistel, Bismuth and cobalt minerals as indicators of stringer zones to massive sulphide deposits, Iberian Pyrite Belt, Mineralium Deposita 31 (1996), pp. 1-26. 
Renne et al., 1998 P.R. Renne, C.C. Swisher, A.L. Deino, D.B. Karner, T.L. Owens and D.J. DePaolo, Intercalibration of standards, absolute ages and uncertainties in ${ }^{40} \mathrm{Ar} /{ }^{39} \mathrm{Ar}$ dating, Chemical Geology 145 (1998), pp. 117-152

Ruffet et al., 1995 G. Ruffet, G. Féraud, M. Balèvre and J.-R. Kiénast, Plateau ages and excess argon in phengites: an ${ }^{40} \mathrm{Ar}-{ }^{39} \mathrm{Ar}$ laser probe study of Alpine micas (Sesia Zone, Western Alps, northern Italy), Chemical Geology (Isotopic Geoscience Section) 121 (1995), pp. 327-343.

Ruffet et al., 1997 G. Ruffet, G. Gruau, M. Ballèvre, G. Féraud and P. Philippot, Rb-Sr and ${ }^{40} \mathrm{Ar}-{ }^{39} \mathrm{Ar}$ laser probe dating of high-pressure phengites from the Sesia zone (western Alps): underscoring of excess argon and new age constraints on the high-pressure metamorphism, Chemical Geology 141 (1997), pp. 1-18.

Sato, 1975 K. Sato, Unilateral isotopic variation of Miocene ore leads from Japan, Economic Geology 70 (1975), pp. 800-805.

Scott, 1983 S.D. Scott, Chemical behaviour of sphalerite and arsenopyrite in hydrothermal and metamorphic environments, Mineralogical Magazine 47 (1983), pp. 427-435.

Sharpe and Gemmel, 2002 R. Sharpe and J.B. Gemmel, The Archean $\mathrm{Cu}-\mathrm{Zn}$ magnetite-rich Gossan Hill volcanic-hosted massive sulfide deposit, Western Australia: genesis of a multistage hydrothermal system, Economic Geology 97 (2002), pp. 517-539.

Stacey and Kramers, 1975 J.D. Stacey and J.D. Kramers, Approximation of terrestrial lead isotope evolution by a two-stage model, Earth and Planetary Science Letters 26 (1975), pp. $207-221$.

Steiger and Jäger, 1977 R.H. Steiger and E. Jäger, Subcommission on geochronology: convention on the use of decay constants in geo- and cosmochronology, Earth and Planetary Science Letters 36 (1977), pp. 359-362.

Tatsumoto et al., 1972 M. Tatsumoto, R.J. Knight and M.H. Delevaux, Uranium, thorium, and lead concentrations in three silicate standards and a method of lead isotopic analysis, USGS Professional Paper vol. 800-D (1972), pp. 111-115.

Todt et al., 1984 W. Todt, R.A. Cliff, A. Hanser and A.W. Hofmann, ${ }^{202} \mathrm{~Pb}-{ }^{205} \mathrm{~Pb}$ spike for $\mathrm{Pb}$ isotopic analysis, Terra Cognita 4 (1984), p. 209.

Vaughan and Craig, 1997 D.J. Vaughan and J.R. Craig, Sulfide ore mineral stabilities, morphologies and intergrowth textures. In: H.L. Barnes, Editor, Geochemistry of Hydrothermal Ore Deposits (3rd edition), John Wiley and Sons, New York (1997), pp. 367434. 


\section{Figures}

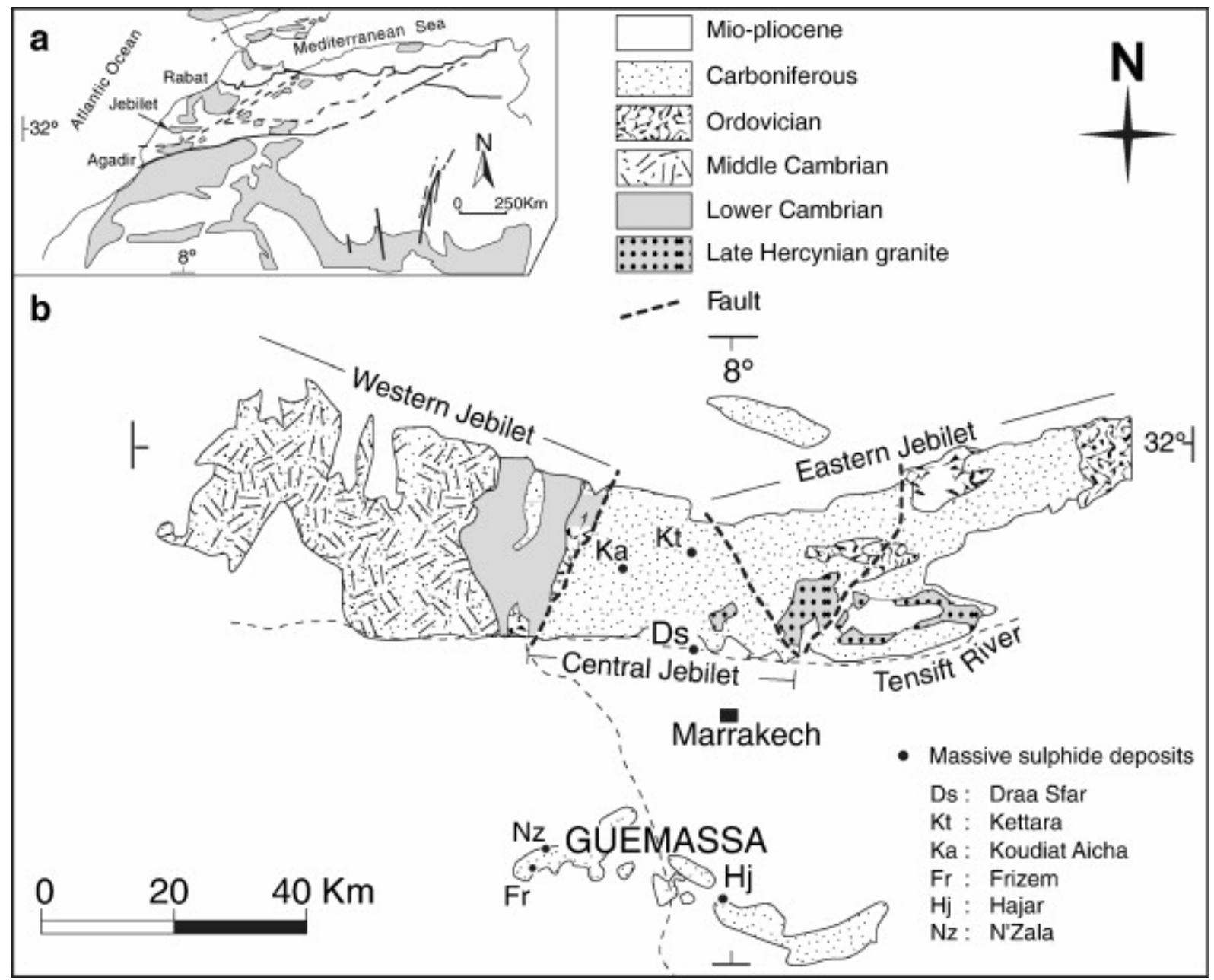

Fig. 1. (a) The location of the Jebilet massif and the distribution of Palaeozoic rocks of North Africa (in grey). (b) General geologic map of the Jebilet and Guemassa Hercynian massifs, around Marrakech, showing the location of the principal massive sulphide deposits (modified from Huvelin, 1977). 


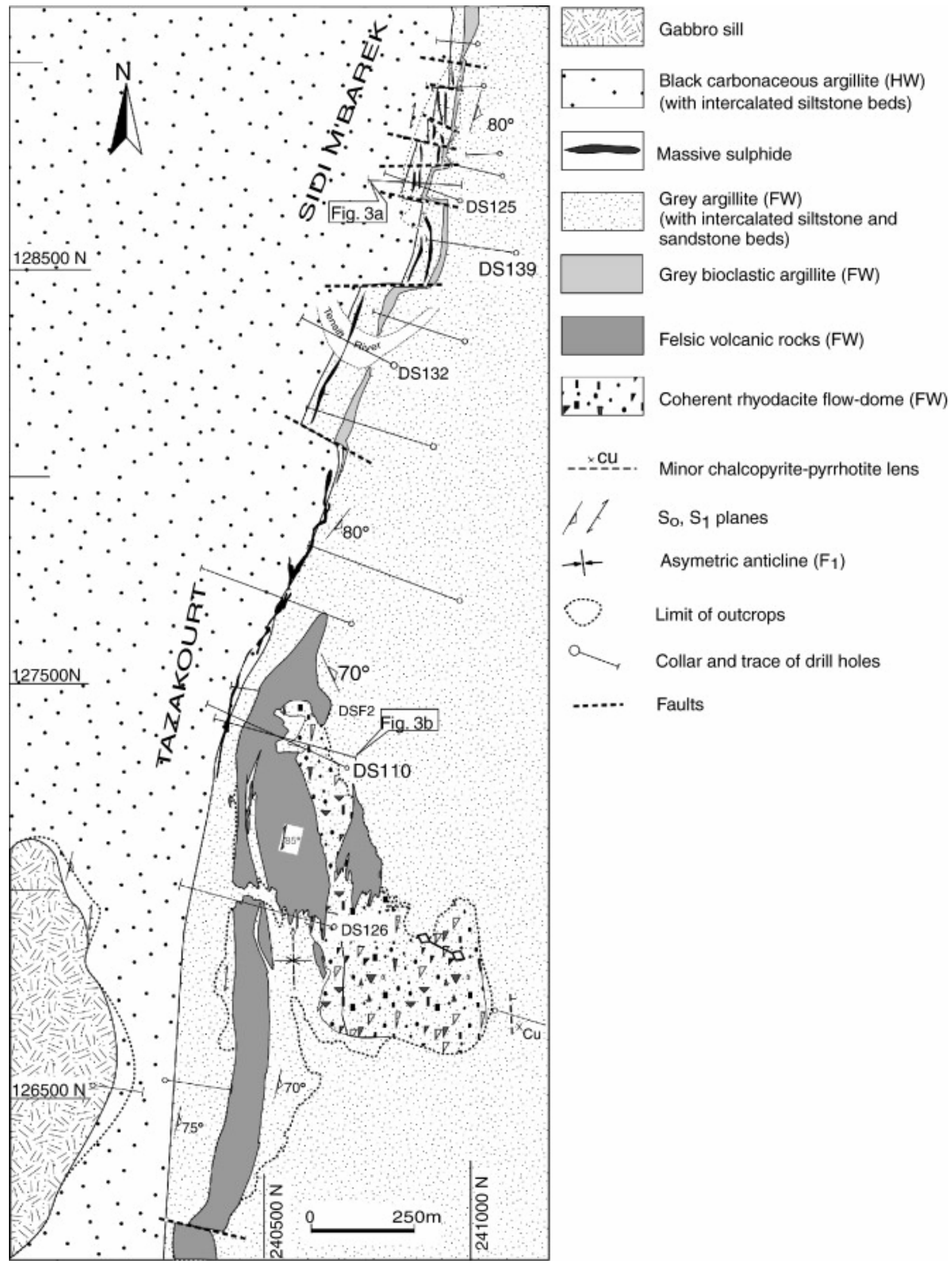

Fig. 2. Geological map of the Draa Sfar area, showing the location of the massive sulphide orebodies, key geologic units and selected diamond drill holes illustrated in Fig. 3 and Fig. 5. 
W

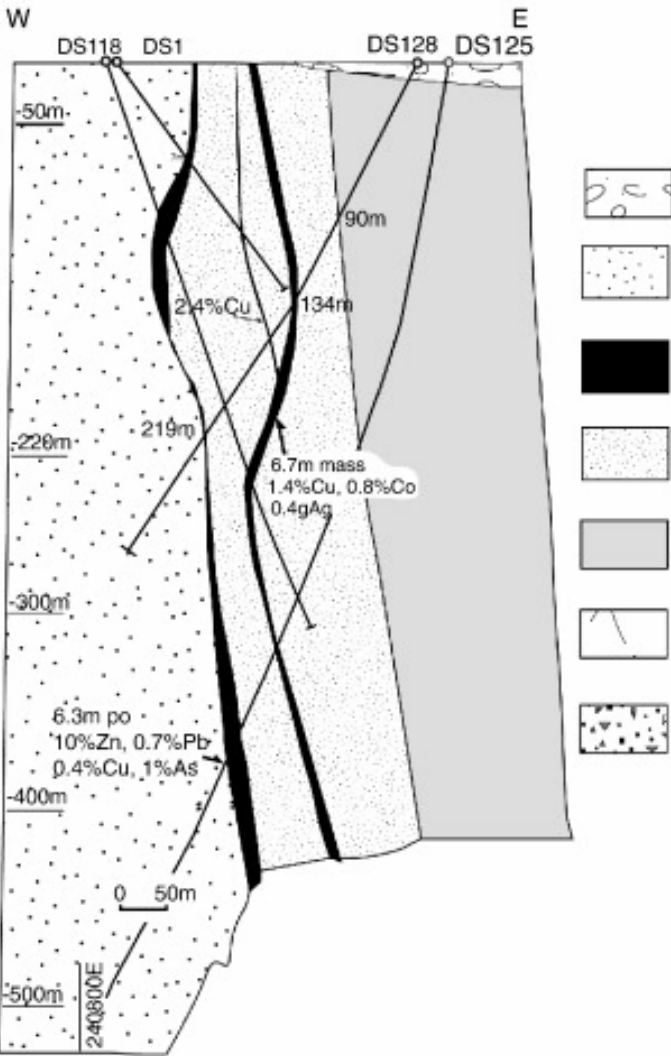

\section{Overburden}

Black carboneceous argillite $(\mathrm{HW})$ (with intercalated siltstone beds)

Massive sulphide

Grey argillite (FW)

(with intercalated siltstone and sandstone beds)

Grey bioclastic argillite (FW)

Coherent rhyodacite flow-dome (FW

Felsic volcaniclastic rocks (FW)

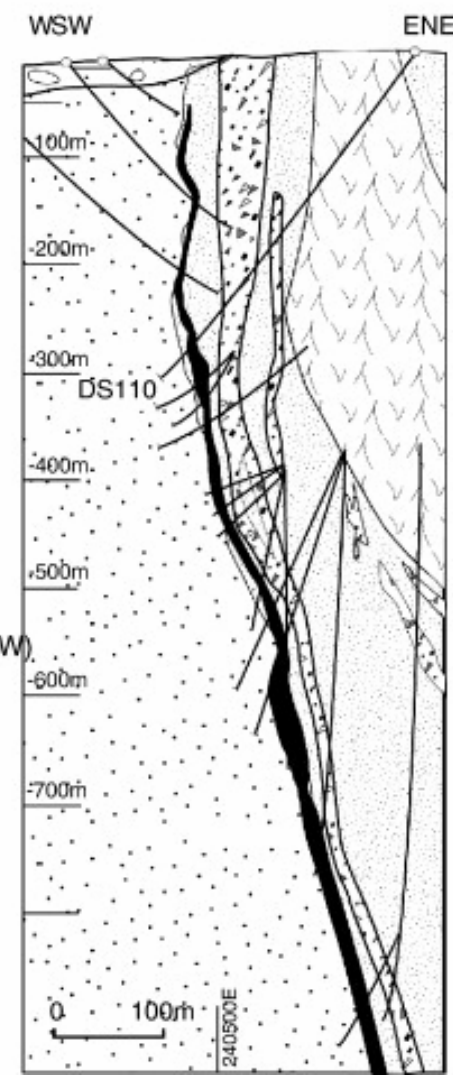

Fig. 3. Vertical east-west cross sections looking north through the Draa Sfar deposit showing the main ore zones and mine stratigraphy. To improve clarity, the mafic dykes and sills are not shown. 

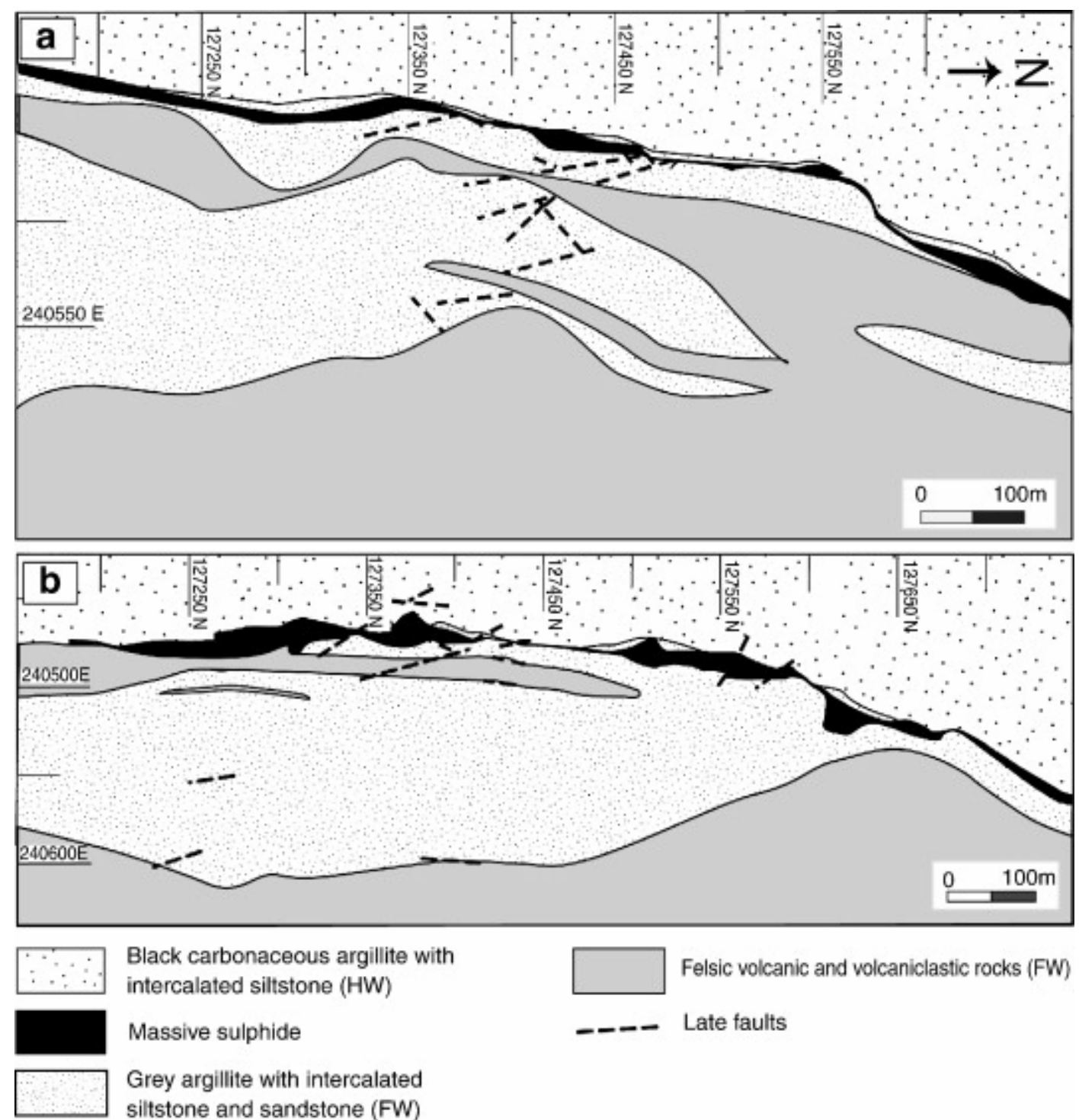

Black carbonaceous argillite with intercalated siltstone (HW)

Massive sulphide

Felsic volcanic and volcaniclastic rocks (FW)

Grey argillite with intercalated

siltstone and sandstone (FW)

Fig. 4. Simplified geological map of the (a) -300 and (b) - $400 \mathrm{~m}$ levels through the Tazakourt orebody, showing the sheet-like and boudinaged form of the sulphide lens. 


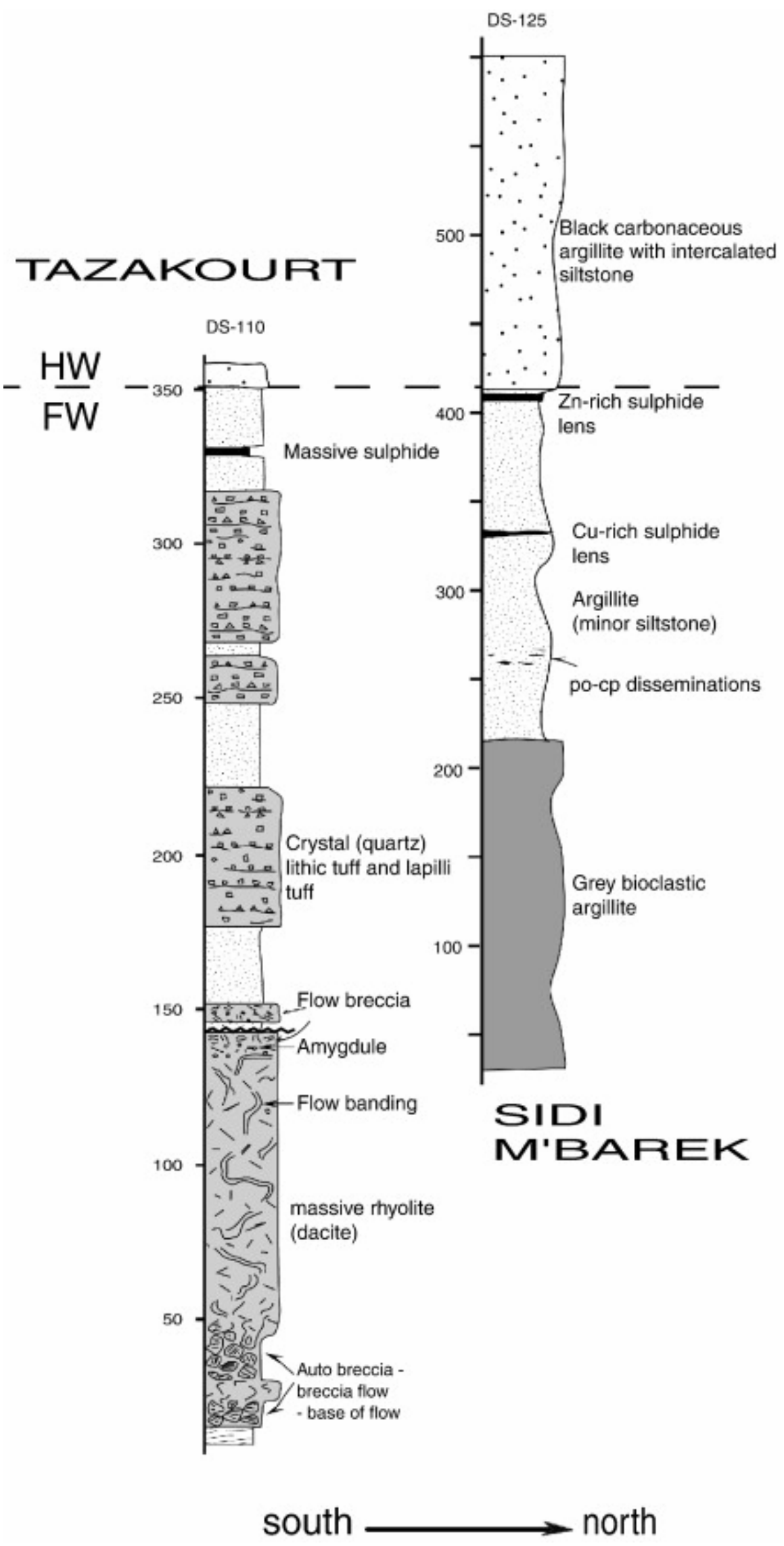

Fig. 5. Restored east-west stratigraphic sections of the Draa Sfar mine stratigraphy, as determined from detail logging of boreholes DS110 and DS125. 

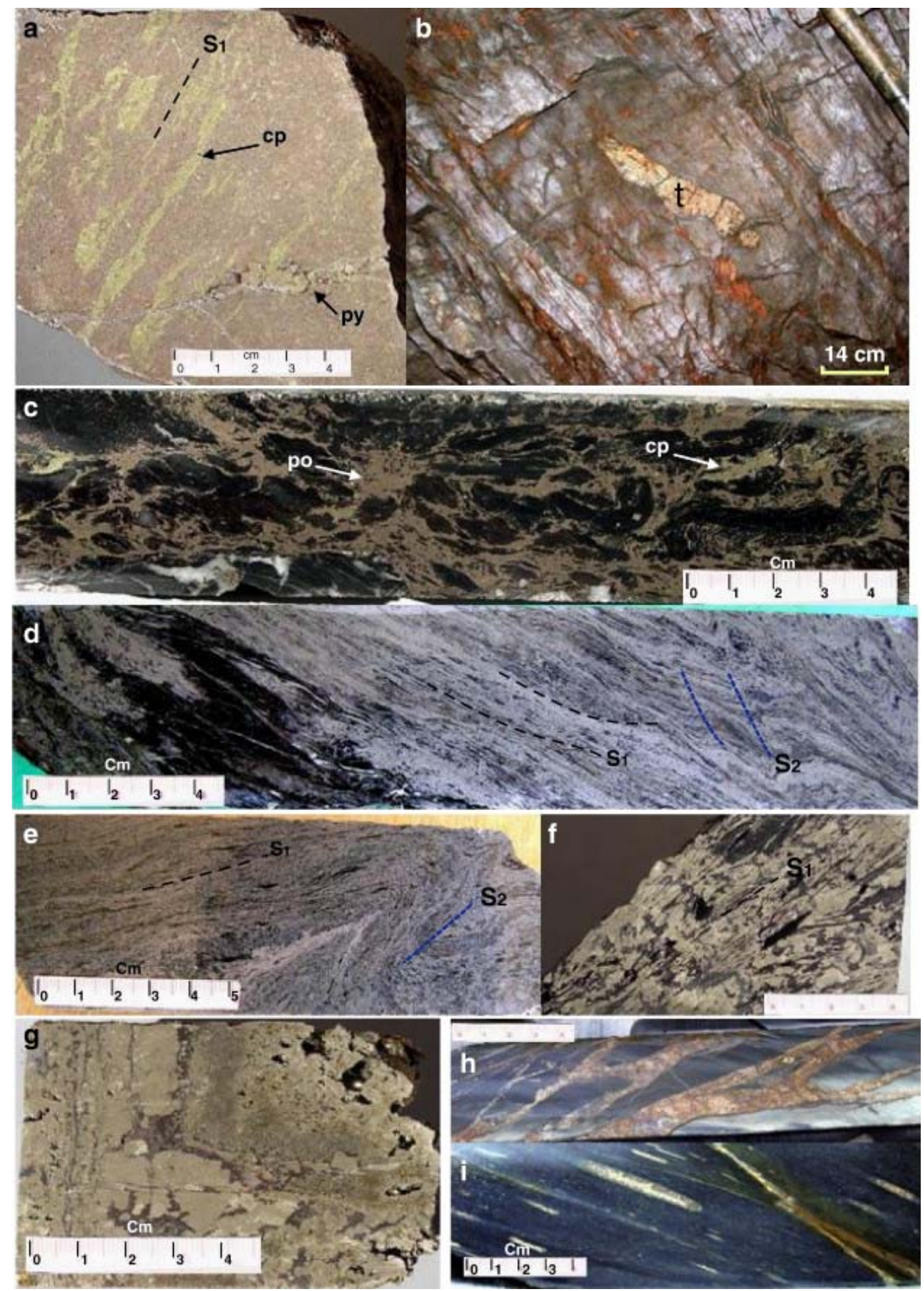

Fig. 6. Photographs of the macroscopic and structural habit of the massive sulphide ore; (a) Polished sample showing the $\mathrm{S} 1$ foliation within sulphides marked by the elongation of chalcopyrite $(\mathrm{CP})$ within pyrrhotite (PO), and a later fracture filled with pyrite (PY). (b) View of the hanging wall of a mine gallery showing a relict of talc-chlorite rimmed by sulphides (t). (c) Polished sample showing 'durchbewegung' texture developed within a highly deformed pyrrhotite-rich matrix. Note the differential remobilization, flow, of chalcopyrite (CP) versus pyrrhotite (PO). (d), (e) Polished samples illustrating the pronounced $\mathrm{S}_{1}-\mathrm{S}_{2}$ foliations and a D1 isoclinal microfold that developed within massive pyrrhotite. (f) Polished sample showing possible pre-tectonic primary pyrite (northern zone of the mine) (g) Polished sample with cataclastic, secondary pyrite (white-yellow) filled by hematite (brown). Polished samples of footwall argillite: (h) pyrrhotite (red-brown) within a fracture network; (i) deformed nodules of disseminated pyrrhotite-chalcopyrite within argillite. Note: Photos scale in $\mathrm{cm}$. 

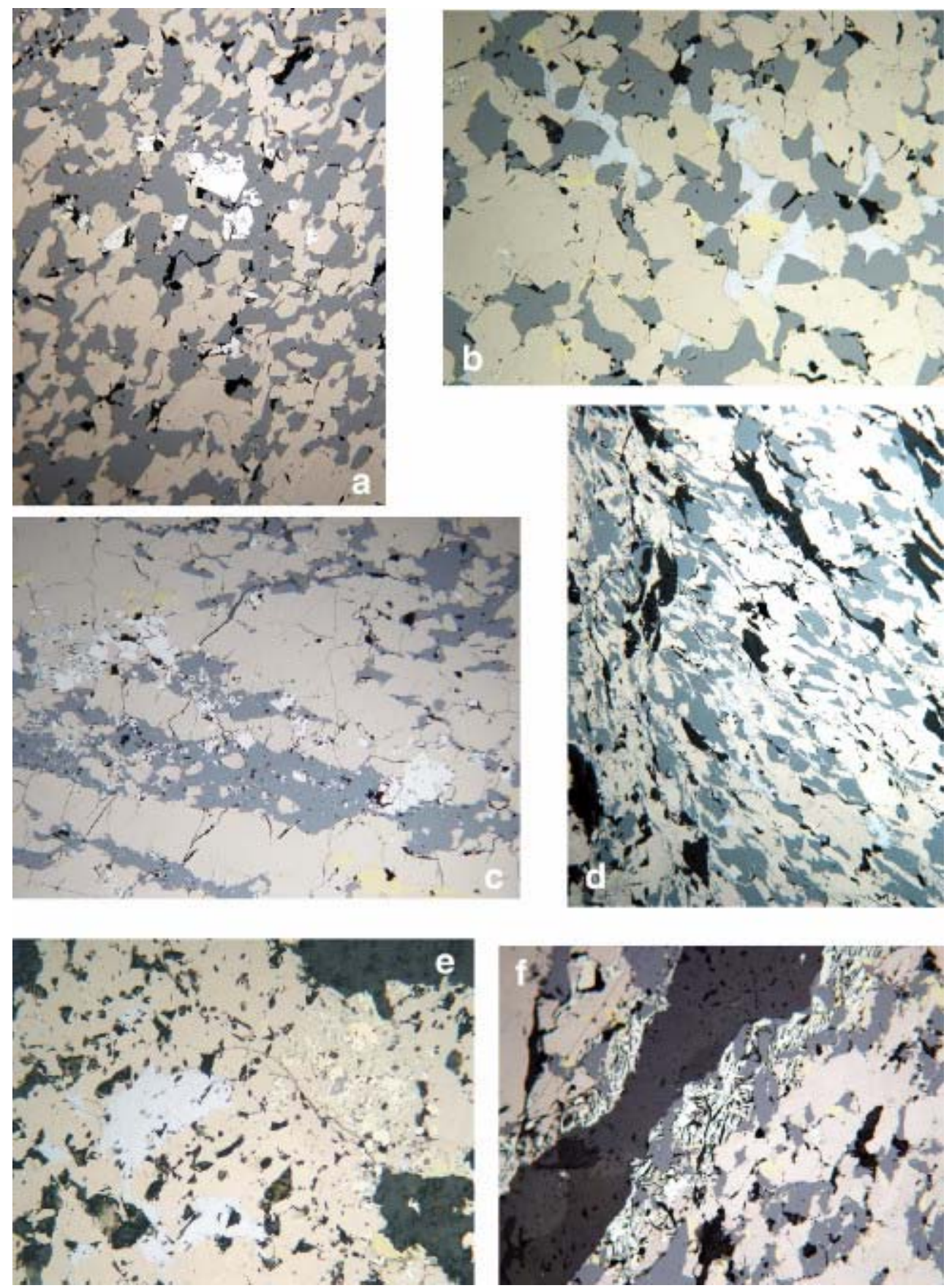

Fig. 7. Reflected, plane-polarized light photomicrographs of Tazakourt orebody. (a) Typical pyrrhotite (pale brown)-sphalerite (gray) ore with disseminated, automorphic arsenopyrite crystals (white) (DS 125, 345 m). Width of field of view: $0.8 \mathrm{~mm}$. (b) Polymetallic ore with pyrrhotite (pale brown), sphalerite (gray), chalcopyrite (yellow) and galena (white) (south crosscut, $120 \mathrm{~m}$ ). Width of field of view: $0.8 \mathrm{~mm}$. (c) Banded ore with pyrrhotite- and sphalerite-rich bands and accessory arsenopyrite (DDH DS 125, $404 \mathrm{~m}$ ). Width of field of view: $0.8 \mathrm{~mm}$. (d) Pyrrhotite-early (primary?) pyrite (yellow-white) and sphalerite (gray) ore showing S planes striking NW-SE and C planes striking E-W (DDH DS 110-38, $330 \mathrm{~m}$ ). Width of field of view: $0.8 \mathrm{~mm}$. (e) Secondary pyrite (pale yellow) and magnetite (gray) in pyrrhotite (DS 125, $404 \mathrm{~m}$ ). Width of field of view: $0.8 \mathrm{~mm}$. (f) Late carbonate veinlet with an envelope of marcasite (yellow-white) that formed by the replacement of pyrrhotite (south crosscut $120 \mathrm{~m}$ ). Width of field of view: $0.4 \mathrm{~mm}$. 


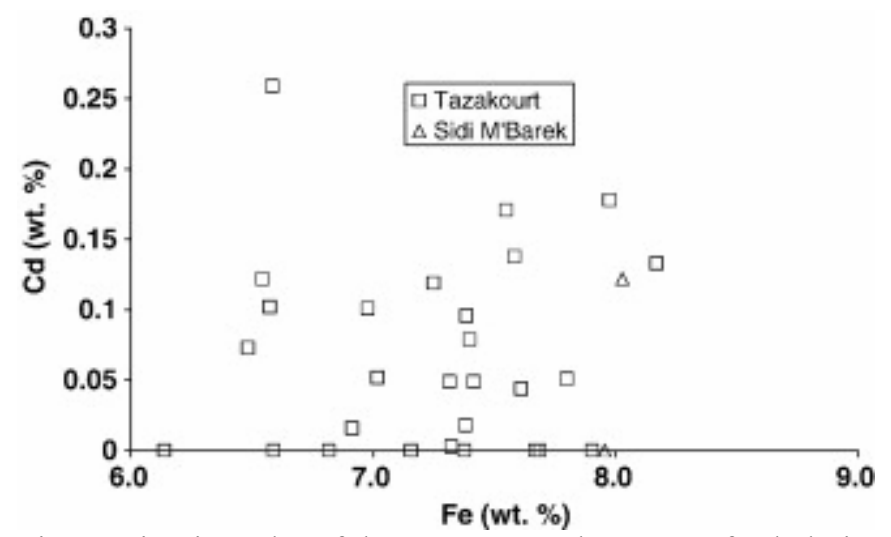

Fig. 8. Bivariate plot of the Fe versus Cd content of sphalerite (see Table 2). Electron microprobe analyses, BRGM-ISTO laboratory, Orleans, France.
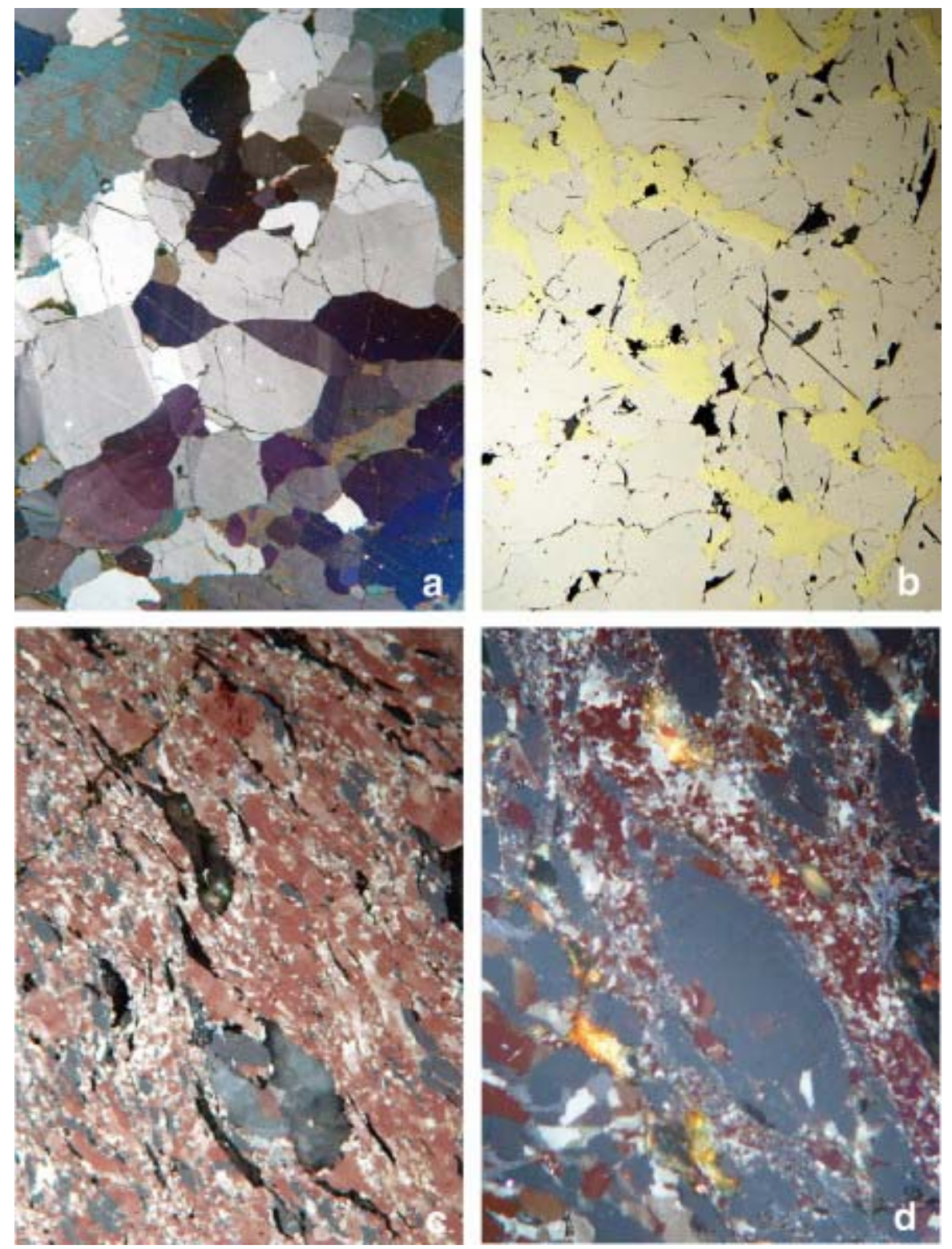

Fig. 9. Reflected light photomicrographs illustrating ore deformation features. (a) Contiguous equigranular pyrrhotite (grey, purple and brown) and chalcopyrite (dark blue) with a polygonal texture and $120{ }^{\circ} \mathrm{C}$ angles. Sidi M'Barek Cu lens DS 128, $139.5 \mathrm{~m}$. Crossed nicols; width of field of view is $1.2 \mathrm{~mm}$. (b) Contiguous equigranular pyrrhotite (light brown) and chalcopyrite (yellow) with a polygonal texture and $120^{\circ} \mathrm{C}$ angles. Sidi 
M'Barek. Cu lens DS 128, $139.5 \mathrm{~m}$. Parallel nicols; width of field of view is $1.2 \mathrm{~mm}$. Photomicrographs a and b are features typical of a metamorphic recrystallization. (c) and (d) mylonitic microfabric in massive sulphide (red brown and white) and quartz (dark grey) characterized by the development of $S_{1}$ and $S_{2}$ foliations $\left(C, C^{\prime}\right.$ and $S$ planes), dislocation planes, pressure lamellae, and pressure shadows imparting a fusiform habit. Tazakourt orebody, DS $110-38,330 \mathrm{~m}$. Crossed nicols; width of field of view is $0.4 \mathrm{~mm}$ for $\mathrm{c}$ and $\mathrm{d}$.

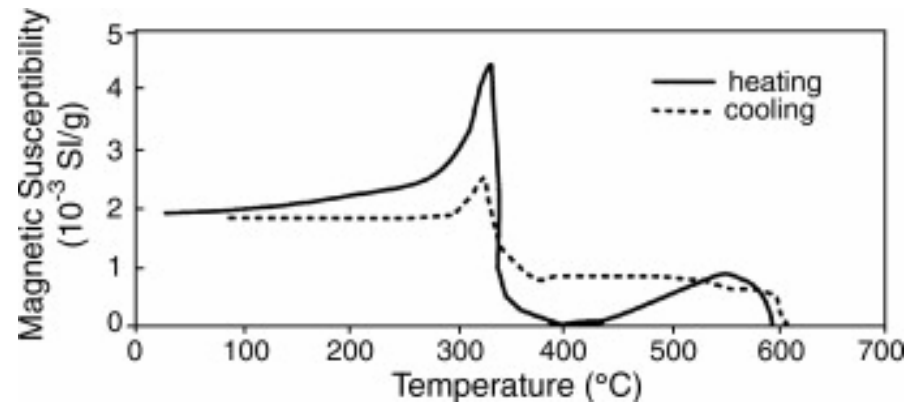

Fig. 10. Thermomagnetic profiles of the pyrrhotite ore. 


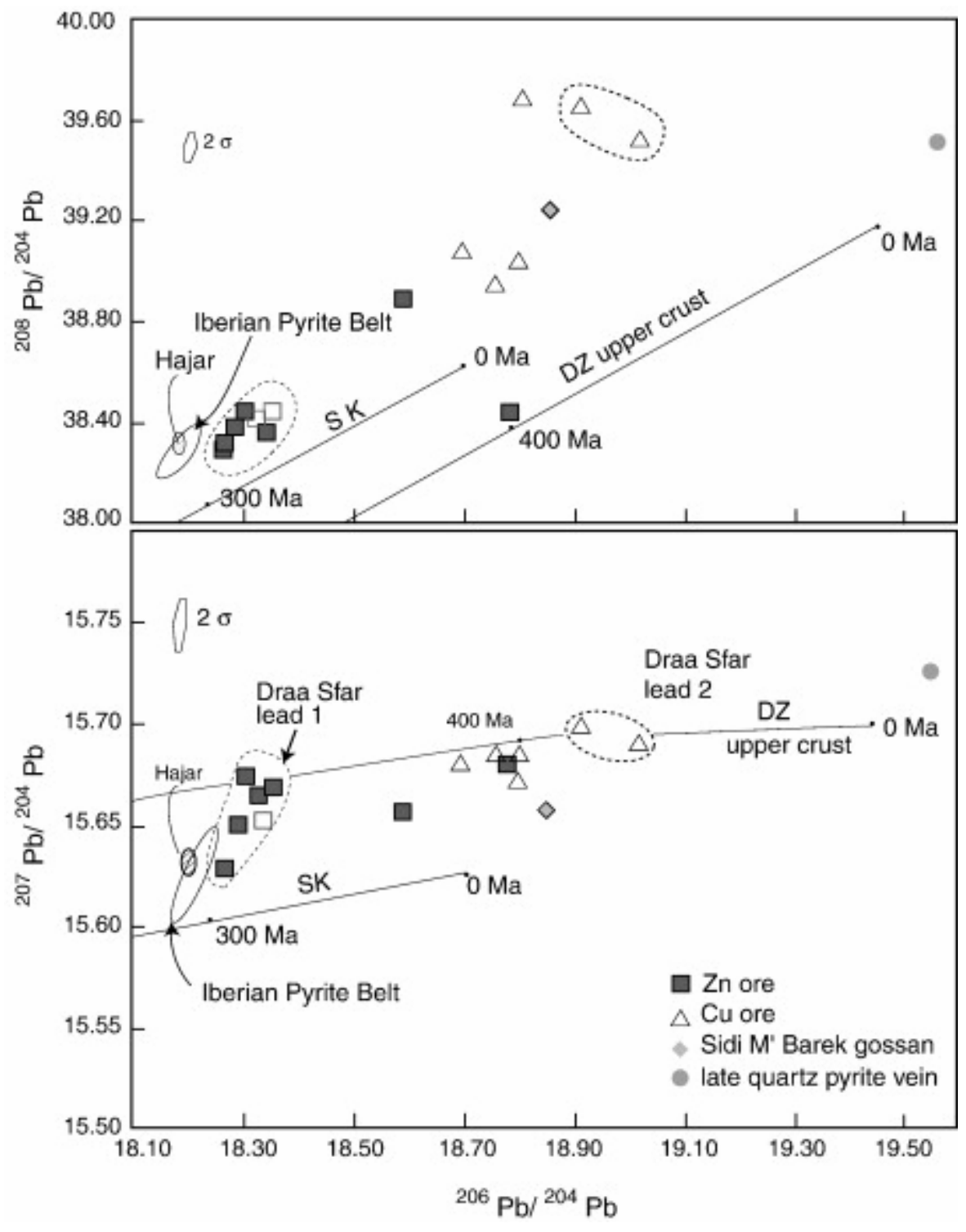

Fig. 11. Lead isotopic compositions of the Draa Sfar ores. Also shown are the lead isotopic compositions for Hajar and for the IPB VMS for comparison (data from Marcoux, 1998). SK: average growth curve of Stacey and Kramers (1975), DZ: upper crust growth curve of Doe and Zartman (1979). 


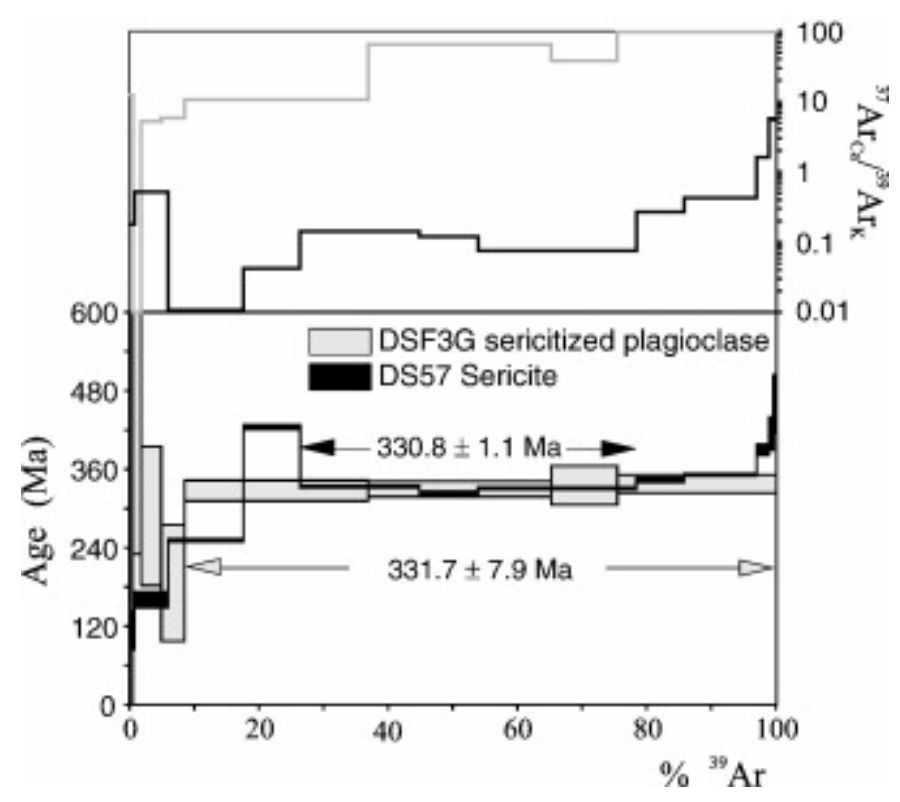

Fig. $12 .{ }^{39} \mathrm{Ar}-{ }^{40} \mathrm{Ar}$ age spectra. The age error bars for each temperature steps are at the 1 level and do not include errors in the $J$-values. The errors in the $J$-values are included in the plateau age calculations. 

Tables

Table 1. : Summary of the main characteristics of the Jebilet and Guemassa VMS deposits

\begin{tabular}{|c|c|c|c|c|c|}
\hline \multicolumn{2}{|l|}{ Domain } & \multicolumn{3}{|l|}{ Jebilet } & \multirow{2}{*}{$\begin{array}{l}\text { Guemassa } \\
\text { Hajar }\end{array}$} \\
\hline \multicolumn{2}{|c|}{ VMS deposit } & Draa Sfar & Kettara & Koudiat Aïcha & \\
\hline & Location & $15 \mathrm{~km} \mathrm{NW}$ of Marrakech & $32 \mathrm{~km}$ NNE of Marrakech & $28 \mathrm{~km} \mathrm{NW}$ of Marrakech & $23 \mathrm{~km} \mathrm{~S}$ of Marrakech \\
\hline & Tonnes (Mt) & 10 & 30 & 4.5 & 20 \\
\hline \multirow[t]{6}{*}{ Geology } & Grade & $\begin{array}{l}5 \text { wt. } \% \mathrm{Zn}, 1.2 \text { wt. } \% \mathrm{~Pb} \text {, } \\
0.5 \text { wt. } \% \mathrm{Cu}\end{array}$ & 55 wt. $\% \mathrm{Fe}, 0.7$ wt. $\% \mathrm{Cu}$ & $\begin{array}{l}2.7 \text { wt. } \% \mathrm{Zn}, 1 \text { wt. } \% \text { Pb, } 0.5 \text { wt. } \% \\
\mathrm{Cu}\end{array}$ & $\begin{array}{l}8 \text { wt. } \% \text { Zn, } 3 \text { wt. } \% \text { Pb, } 0.5 \text { wt. } \% \\
\text { Cu, } 60 \text { g/t Ag }\end{array}$ \\
\hline & $\begin{array}{l}\text { Main ore } \\
\text { minerals }\end{array}$ & $\begin{array}{l}\text { Pyrrhotite, chalcopyrite, } \\
\text { sphalerite, arsenopyrite, galena, } \\
\text { calcite, quartz, chlorite }\end{array}$ & $\begin{array}{l}\text { Pyrrhotite, pyrite, chalcopyrite, } \\
\text { sphalerite, arsenopyrite, galena, } \\
\text { calcite, quartz, chlorite }\end{array}$ & $\begin{array}{l}\text { Pyrrhotite, pyrite, chalcopyrite, } \\
\text { sphalerite, arsenopyrite, galena, } \\
\text { calcite, quartz, chlorite }\end{array}$ & $\begin{array}{l}\text { Pyrrhotite, pyrite, chalcopyrite, } \\
\text { sphalerite, arsenopyrite, galena, } \\
\text { calcite, quartz, chlorite }\end{array}$ \\
\hline & Gossan & Yes & Yes & Yes & Yes \\
\hline & Host rocks & Volcano-sedimentary & Volcano-sedimentary & Volcano-sedimentary & Volcano-sedimentary \\
\hline & Deformation & Major & Major & Major & Major \\
\hline & Age & Visean & Visean & Visean & Visean \\
\hline
\end{tabular}


Table 2. : Electron microprobe analyses of sulphide minerals that constitute the Draa Sfar deposit

\begin{tabular}{|c|c|c|c|c|c|c|c|c|c|c|c|c|c|c|c|c|}
\hline & \multicolumn{16}{|c|}{ Pyrrhotite } \\
\hline & $\begin{array}{l}\text { Tazako } \\
\text { urt }\end{array}$ & $\begin{array}{l}\text { Tazako } \\
\text { urt }\end{array}$ & $\begin{array}{l}\text { Tazako } \\
\text { urt }\end{array}$ & $\begin{array}{l}\text { Tazako } \\
\text { urt }\end{array}$ & $\begin{array}{l}\text { Tazakour } \\
\mathrm{t}\end{array}$ & $\begin{array}{l}\text { Tazako } \\
\text { urt }\end{array}$ & $\begin{array}{l}\text { Tazako } \\
\text { urt }\end{array}$ & $\begin{array}{l}\text { Tazako } \\
\text { urt }\end{array}$ & $\begin{array}{l}\text { Tazako } \\
\text { urt }\end{array}$ & $\begin{array}{l}\text { Tazako } \\
\text { urt }\end{array}$ & $\begin{array}{l}\text { Tazako } \\
\text { urt }\end{array}$ & $\begin{array}{l}\text { Tazako } \\
\text { urt }\end{array}$ & $\begin{array}{l}\text { Tazako } \\
\text { urt }\end{array}$ & $\begin{array}{l}\text { Tazako } \\
\text { urt }\end{array}$ & \multicolumn{2}{|l|}{$\begin{array}{l}\text { Tazako } \\
\text { urt }\end{array}$} \\
\hline & DS 7 & DS 7 & DS 7 & DS 7 & DS 7 & DS 7 & DS 1 & DS 1 & DS 1 & DS 1 & $\begin{array}{l}\text { DS } \\
110 / 37\end{array}$ & $\begin{array}{l}\text { DS } \\
110 / 37\end{array}$ & $\begin{array}{l}\text { DS } \\
110 / 37\end{array}$ & DS2 & DS2 & \\
\hline $\mathrm{Fe}$ & 60.45 & 60.48 & 60.03 & 60.18 & 60.31 & 60.40 & 60.54 & 59.88 & 59.68 & 59.66 & 60.09 & 59.77 & 60.27 & 59.88 & 60.02 & \\
\hline S & 39.43 & 39.55 & 39.32 & 39.68 & 39.69 & 39.84 & 39.53 & 39.76 & 39.52 & 39.67 & 39.57 & 39.76 & 39.56 & 39.46 & 39.73 & \\
\hline As & 0.06 & 0.07 & 0.06 & 0.13 & 0.03 & 0.11 & 0.00 & 0.03 & 0.03 & 0.02 & 0.06 & 0.09 & 0.08 & 0.04 & 0.04 & \\
\hline $\mathrm{Co}$ & 0.00 & 0.00 & 0.00 & 0.00 & 0.00 & 0.02 & 0.00 & 0.00 & 0.00 & 0.01 & 0.00 & 0.01 & 0.05 & 0.02 & 0.05 & \\
\hline $\mathrm{Bi}$ & 0.10 & 0.00 & 0.03 & 0.16 & 0.20 & 0.13 & 0.04 & 0.00 & 0.12 & 0.00 & 0.12 & 0.21 & 0.00 & 0.04 & 0.13 & \\
\hline Total & 100.05 & 100.10 & 99.45 & 100.14 & 100.23 & 100.50 & 100.11 & 99.66 & 99.34 & 99.35 & 99.84 & 99.84 & 99.95 & 99.43 & 99.98 & \\
\hline Fe cat & 46.73 & 46.74 & 46.69 & 46.49 & 46.57 & 46.49 & 46.79 & 46.26 & 46.42 & 46.32 & 46.55 & 46.28 & 46.62 & 46.53 & 46.40 & \\
\hline$S$ cat & 53.09 & 53.22 & 53.27 & 53.39 & 53.37 & 53.41 & 53.20 & 53.51 & 53.54 & 53.64 & 53.39 & 53.62 & 53.30 & 53.41 & 53.50 & \\
\hline \multirow[t]{3}{*}{$\mathrm{XFeS}$} & 0.93 & 0.93 & 0.93 & 0.93 & 0.93 & 0.93 & 0.94 & 0.93 & 0.93 & 0.93 & 0.93 & 0.93 & 0.93 & 0.93 & 0.93 & \\
\hline & $\begin{array}{l}\text { Tazako } \\
\text { urt }\end{array}$ & $\begin{array}{l}\text { Tazako } \\
\text { urt }\end{array}$ & $\begin{array}{l}\text { Tazako } \\
\text { urt }\end{array}$ & $\begin{array}{l}\text { Tazako } \\
\text { urt }\end{array}$ & $\begin{array}{l}\text { Tazakour } \\
\mathrm{t}\end{array}$ & $\begin{array}{l}\text { Tazako } \\
\text { urt }\end{array}$ & $\begin{array}{l}\text { Tazako } \\
\text { urt }\end{array}$ & $\begin{array}{l}\text { Tazako } \\
\text { urt }\end{array}$ & $\begin{array}{l}\text { Tazako } \\
\text { urt }\end{array}$ & $\begin{array}{l}\text { Tazako } \\
\text { urt }\end{array}$ & $\begin{array}{l}\text { Tazako } \\
\text { urt }\end{array}$ & $\begin{array}{l}\text { Tazako } \\
\text { urt }\end{array}$ & $\begin{array}{l}\text { Tazako } \\
\text { urt }\end{array}$ & $\begin{array}{l}\text { Tazako } \\
\text { urt }\end{array}$ & $\begin{array}{l}\text { Averag } \\
\mathrm{e} \\
\text { Tazako } \\
\text { urt }\end{array}$ & \\
\hline & DS2 & $\begin{array}{l}\text { DS } \\
125 \mathrm{~b}\end{array}$ & $\begin{array}{l}\mathrm{DS} \\
125 \mathrm{~b}\end{array}$ & $\begin{array}{l}\mathrm{DS} \\
125 \mathrm{~b}\end{array}$ & DS $125 b$ & DS 23 & DS 23 & DS 23 & DS 23 & DS 23 & DS 23 & DS 23 & DS 22 & DS 22 & & \\
\hline
\end{tabular}




\begin{tabular}{|c|c|c|c|c|c|c|c|c|c|c|c|c|c|c|c|}
\hline $\mathrm{Fe}$ & 60.17 & 60.71 & 61.03 & 60.54 & 60.50 & 61.03 & 60.58 & 60.56 & 60.68 & 60.58 & 60.66 & 60.81 & 60.58 & 60.18 & 60.35 \\
\hline $\mathrm{S}$ & 39.48 & 39.64 & 40.01 & 40.03 & 40.07 & 40.05 & 39.70 & 40.08 & 39.87 & 39.69 & 39.98 & 39.75 & 39.68 & 39.67 & 39.72 \\
\hline As & 0.08 & 0.10 & 0.04 & 0.02 & 0.03 & 0.10 & 0.10 & 0.00 & 0.12 & 0.06 & 0.05 & 0.06 & 0.09 & 0.05 & 0.06 \\
\hline $\mathrm{Co}$ & 0.00 & 0.00 & 0.03 & 0.01 & 0.03 & 0.01 & 0.18 & 0.08 & 0.09 & 0.00 & 0.00 & 0.04 & 0.05 & 0.05 & 0.02 \\
\hline $\mathrm{Bi}$ & 0.02 & 0.03 & 0.04 & 0.00 & 0.00 & 0.02 & 0.00 & 0.20 & 0.09 & 0.07 & 0.00 & 0.00 & 0.07 & 0.13 & 0.07 \\
\hline Total & 99.74 & 100.48 & 101.15 & 100.60 & 100.63 & 101.21 & 100.56 & 100.92 & 100.85 & 100.40 & 100.69 & 100.67 & 100.47 & 100.09 & 100.22 \\
\hline Fe cat & 46.62 & 46.75 & 46.67 & 46.47 & 46.41 & 46.63 & 46.61 & 46.40 & 46.57 & 46.68 & 46.54 & 46.72 & 46.62 & 46.51 & 46.55 \\
\hline$S$ cat & 53.28 & 53.17 & 53.29 & 53.51 & 53.53 & 53.30 & 53.21 & 53.49 & 53.28 & 53.27 & 53.43 & 53.20 & 53.19 & 53.39 & 53.36 \\
\hline XFeS & 0.93 & 0.93 & 0.93 & 0.93 & 0.93 & 0.93 & 0.93 & 0.93 & 0.93 & 0.93 & 0.93 & 0.93 & 0.93 & 0.93 & 0.93 \\
\hline & $\begin{array}{l}\text { Sidi } \\
\text { M'Bare } \\
\text { k }\end{array}$ & $\begin{array}{l}\text { Sidi } \\
\text { M'Bare } \\
\text { k }\end{array}$ & $\begin{array}{l}\text { Sidi } \\
\text { M'Bare } \\
\text { k }\end{array}$ & $\begin{array}{l}\text { Sidi } \\
\text { M'Bare } \\
\text { k }\end{array}$ & $\begin{array}{l}\text { Sidi } \\
\text { M'Barek }\end{array}$ & $\begin{array}{l}\text { Sidi } \\
\text { M'Bare } \\
\text { k }\end{array}$ & $\begin{array}{l}\text { Sidi } \\
\text { M'Bare } \\
\text { k }\end{array}$ & $\begin{array}{l}\text { Sidi } \\
\text { M'Bare } \\
\text { k }\end{array}$ & $\begin{array}{l}\text { Averag } \\
\text { e Sidi } \\
\text { M'Bare } \\
\text { k }\end{array}$ & & & & & & \\
\hline & DS 128 & DS 128 & DS 128 & DS 128 & DS 128 & DS 128 & DS 25 & DS 25 & & & & & & & \\
\hline $\mathrm{Fe}$ & 60.69 & 60.17 & 60.88 & 59.85 & 60.18 & 59.90 & 60.13 & 60.34 & 60.27 & & & & & & \\
\hline $\mathrm{S}$ & 39.70 & 39.78 & 40.08 & 39.81 & 39.93 & 39.62 & 39.81 & 39.62 & 39.79 & & & & & & \\
\hline As & 0.11 & 0.08 & 0.09 & 0.00 & 0.07 & 0.03 & 0.00 & 0.15 & 0.07 & & & & & & \\
\hline Co & 0.05 & 0.11 & 0.09 & 0.11 & 0.07 & 0.10 & 0.13 & 0.08 & 0.09 & & & & & & \\
\hline $\mathrm{Bi}$ & 0.00 & 0.11 & 0.05 & 0.04 & 0.03 & 0.01 & 0.11 & 0.00 & 0.04 & & & & & & \\
\hline Total & 100.55 & 100.24 & 101.19 & 99.81 & 100.27 & 99.65 & 100.17 & 100.19 & 100.26 & & & & & & \\
\hline
\end{tabular}




\begin{tabular}{|c|c|c|c|c|c|c|c|c|c|c|c|c|c|c|c|c|}
\hline Fe cat & 46.66 & 46.39 & 46.51 & 46.27 & 46.35 & 46.41 & 46.38 & 46.58 & 46.44 & & & & & & & \\
\hline$S$ cat & 53.15 & 53.42 & 53.33 & 53.61 & 53.56 & 53.46 & 53.48 & 53.27 & 53.41 & & & & & & & \\
\hline \multirow[t]{4}{*}{$\mathrm{XFeS}$} & 0.933 & 0.928 & 0.930 & 0.925 & 0.927 & 0.928 & 0.928 & 0.932 & 0.929 & & & & & & & \\
\hline & \multicolumn{16}{|c|}{ Arsenopyrite } \\
\hline & $\begin{array}{l}\text { Tazako } \\
\text { urt }\end{array}$ & $\begin{array}{l}\text { Tazako } \\
\text { urt }\end{array}$ & $\begin{array}{l}\text { Tazako } \\
\text { urt }\end{array}$ & $\begin{array}{l}\text { Tazako } \\
\text { urt }\end{array}$ & $\begin{array}{l}\text { Tazakour } \\
\mathrm{t}\end{array}$ & $\begin{array}{l}\text { Tazako } \\
\text { urt }\end{array}$ & $\begin{array}{l}\text { Tazako } \\
\text { urt }\end{array}$ & $\begin{array}{l}\text { Tazako } \\
\text { urt }\end{array}$ & $\begin{array}{l}\text { Tazako } \\
\text { urt }\end{array}$ & $\begin{array}{l}\text { Tazako } \\
\text { urt }\end{array}$ & $\begin{array}{l}\text { Tazako } \\
\text { urt }\end{array}$ & $\begin{array}{l}\text { Tazako } \\
\text { urt }\end{array}$ & $\begin{array}{l}\text { Tazako } \\
\text { urt }\end{array}$ & $\begin{array}{l}\text { Tazako } \\
\text { urt }\end{array}$ & $\begin{array}{l}\text { Tazako } \\
\text { urt }\end{array}$ & $\begin{array}{l}\text { Average } \\
\text { Tazakourt }\end{array}$ \\
\hline & DS 7 & DS 7 & DS 7 & \begin{tabular}{|l} 
DS \\
$110 / 37$
\end{tabular} & $\begin{array}{l}\text { DS } \\
110 / 37\end{array}$ & $\begin{array}{l}\text { DS } \\
110 / 37\end{array}$ & $\begin{array}{l}\text { DS } \\
110 / 37\end{array}$ & $\begin{array}{l}\mathrm{DS} \\
125 \mathrm{~b}\end{array}$ & $\begin{array}{l}\text { DS } \\
125 b\end{array}$ & $\begin{array}{l}\mathrm{DS} \\
125 \mathrm{~b}\end{array}$ & $\begin{array}{l}\text { DS } \\
125 b\end{array}$ & $\begin{array}{l}\text { DS } \\
125 b\end{array}$ & $\begin{array}{l}\mathrm{DS} \\
125 \mathrm{~b}\end{array}$ & $\begin{array}{l}\text { DS } \\
125 b\end{array}$ & DS 23 & \\
\hline $\mathrm{Fe}$ & 33.51 & 33.62 & 34.06 & 33.25 & 33.32 & 33.58 & 33.40 & 33.33 & 33.56 & 33.68 & 33.92 & 33.53 & 33.08 & 33.61 & 32.95 & 33.49 \\
\hline S & 20.55 & 20.27 & 20.58 & 20.75 & 20.18 & 20.14 & 20.16 & 19.80 & 20.13 & 20.16 & 20.01 & 19.91 & 20.03 & 19.98 & 18.56 & 20.08 \\
\hline As & 45.62 & 45.70 & 45.88 & 45.24 & 45.52 & 45.59 & 45.64 & 46.89 & 46.78 & 46.43 & 46.37 & 46.75 & 46.44 & 46.69 & 48.24 & 46.25 \\
\hline Co & 0.01 & 0.01 & 0.00 & 0.00 & 0.00 & 0.00 & 0.00 & 0.09 & 0.00 & 0.00 & 0.03 & 0.13 & 0.47 & 0.18 & 0.02 & 0.06 \\
\hline $\mathrm{Se}$ & 0.03 & 0.01 & 0.13 & 0.00 & 0.34 & 0.27 & 0.26 & 0.00 & 0.00 & 0.00 & 0.07 & 0.00 & 0.00 & 0.11 & 0.00 & 0.08 \\
\hline Total & 99.71 & 99.60 & 100.64 & 99.24 & 99.36 & 99.58 & 99.47 & 100.11 & 100.47 & 100.27 & 100.40 & 100.31 & 100.01 & 100.57 & 99.77 & 99.97 \\
\hline \multirow[t]{4}{*}{ As cat } & 32.27 & 32.44 & 32.19 & 32.08 & 32.43 & 32.40 & 32.45 & 33.33 & 33.03 & 32.81 & 32.79 & 33.13 & 32.95 & 32.99 & 34.75 & 32.80 \\
\hline & \multicolumn{16}{|c|}{ Sphalerite } \\
\hline & $\begin{array}{l}\text { Tazako } \\
\text { urt }\end{array}$ & $\begin{array}{l}\text { Tazako } \\
\text { urt }\end{array}$ & $\begin{array}{l}\text { Tazako } \\
\text { urt }\end{array}$ & $\begin{array}{l}\text { Tazako } \\
\text { urt }\end{array}$ & $\begin{array}{l}\text { Tazakour } \\
\mathrm{t}\end{array}$ & $\begin{array}{l}\text { Tazako } \\
\text { urt }\end{array}$ & $\begin{array}{l}\text { Tazako } \\
\text { urt }\end{array}$ & $\begin{array}{l}\text { Tazako } \\
\text { urt }\end{array}$ & $\begin{array}{l}\text { Tazako } \\
\text { urt }\end{array}$ & $\begin{array}{l}\text { Tazako } \\
\text { urt }\end{array}$ & $\begin{array}{l}\text { Tazako } \\
\text { urt }\end{array}$ & $\begin{array}{l}\text { Tazako } \\
\text { urt }\end{array}$ & $\begin{array}{l}\text { Tazako } \\
\text { urt }\end{array}$ & $\begin{array}{l}\text { Tazako } \\
\text { urt }\end{array}$ & $\begin{array}{l}\text { Tazako } \\
\text { urt }\end{array}$ & Average \\
\hline & DS 7 & DS 7 & DS 7 & DS 7 & DS 1 & DS 1 & DS 1 & DS & DS & DS & DS & DS2 & DS2 & DS2 & $\mathrm{DS} 2$ & \\
\hline
\end{tabular}




\begin{tabular}{|c|c|c|c|c|c|c|c|c|c|c|c|c|c|c|c|c|}
\hline & & & & & & & & $110 / 37$ & $110 / 37$ & $110 / 37$ & $110 / 37$ & & & & & \\
\hline $\mathrm{Fe}$ & 7.38 & 7.16 & 5.99 & 6.58 & 7.80 & 7.90 & 7.69 & 8.17 & 6.59 & 6.91 & 7.25 & 7.16 & 7.02 & 7.67 & 6.98 & 7.22 \\
\hline $\mathrm{S}$ & 32.96 & 33.12 & 33.20 & 33.00 & 33.17 & 33.64 & 33.27 & 33.25 & 33.22 & 33.35 & 32.96 & 33.30 & 33.38 & 33.09 & 32.98 & 33.19 \\
\hline $\mathrm{Zn}$ & 58.01 & 59.45 & 60.87 & 60.71 & 58.39 & 58.63 & 59.01 & 58.69 & 60.11 & 59.54 & 59.67 & 59.37 & 59.66 & 56.80 & 59.85 & 59.25 \\
\hline $\mathrm{Cd}$ & 0.10 & 0.00 & 0.00 & 0.26 & 0.05 & 0.00 & 0.00 & 0.13 & 0.00 & 0.02 & 0.12 & 0.00 & 0.05 & 0.00 & 0.10 & 0.06 \\
\hline $\mathrm{Cu}$ & 1.57 & 0.21 & 0.16 & 0.12 & 0.22 & 0.00 & 0.07 & 0.11 & 0.17 & 0.14 & 0.01 & 0.00 & 0.26 & 1.95 & 0.00 & 0.33 \\
\hline Total & 100.02 & 99.94 & 100.23 & 100.67 & 99.62 & 100.17 & 100.03 & 100.35 & 100.09 & 99.96 & 100.00 & 99.83 & 100.37 & 99.51 & 99.91 & 100.05 \\
\hline \multirow[t]{3}{*}{ mole $\% \mathrm{FeS}$} & 11.84 & 11.27 & 9.42 & 10.27 & 12.36 & 12.46 & 12.09 & 12.81 & 10.37 & 10.92 & 11.37 & 11.29 & 11.05 & 12.47 & 10.96 & 11.19 \\
\hline & $\begin{array}{l}\text { Sidi } \\
\text { M'Bare } \\
\mathrm{k}\end{array}$ & $\begin{array}{l}\text { Sidi } \\
\text { M'Bare } \\
\mathrm{k}\end{array}$ & $\begin{array}{l}\text { Sidi } \\
\text { M'Bare } \\
\mathrm{k}\end{array}$ & $\begin{array}{l}\text { Sidi } \\
\text { M'Bare } \\
\mathrm{k}\end{array}$ & $\begin{array}{l}\text { Tazakour } \\
\text { tDS } 125 \mathrm{~b}\end{array}$ & $\begin{array}{l}\text { Tazako } \\
\text { urt DS } \\
125 \mathrm{~b}\end{array}$ & $\begin{array}{l}\text { Tazako } \\
\text { urt DS } \\
125 \mathrm{~b}\end{array}$ & $\begin{array}{l}\text { Tazako } \\
\text { urt DS } \\
125 \mathrm{~b}\end{array}$ & $\begin{array}{l}\text { Tazako } \\
\text { urt DS } \\
23\end{array}$ & $\begin{array}{l}\text { Tazako } \\
\text { urt DS } \\
23\end{array}$ & $\begin{array}{l}\text { Tazako } \\
\text { urt DS } \\
23\end{array}$ & $\begin{array}{l}\text { Tazako } \\
\text { urt DS } \\
23\end{array}$ & $\begin{array}{l}\text { Tazako } \\
\text { urt DS } \\
22\end{array}$ & $\begin{array}{l}\text { Tazako } \\
\text { urt DS } \\
22\end{array}$ & $\begin{array}{l}\text { Averag } \\
\mathrm{e} \\
\end{array}$ & \\
\hline & DS 128 & DS 128 & DS 128 & DS 128 & & & & & & & & & & & & \\
\hline $\mathrm{Fe}$ & 8.03 & 7.96 & 7.94 & 7.81 & 7.41 & 7.55 & 7.38 & 7.40 & 7.58 & 7.98 & 7.61 & 7.32 & 6.48 & 6.54 & 7.50 & \\
\hline $\mathrm{S}$ & 33.51 & 33.01 & 33.34 & 33.21 & 33.48 & 33.57 & 33.54 & 33.46 & 33.87 & 33.45 & 33.22 & 33.45 & 33.44 & 33.54 & 33.43 & \\
\hline $\mathrm{Zn}$ & 58.77 & 58.28 & 59.77 & 59.46 & 60.16 & 59.94 & 60.39 & 60.16 & 59.50 & 59.56 & 60.27 & 59.89 & 60.07 & 60.36 & 59.75 & \\
\hline $\mathrm{Cd}$ & 0.00 & 0.00 & 0.18 & 0.00 & 0.05 & 0.17 & 0.00 & 0.08 & 0.14 & 0.18 & 0.04 & 0.05 & 0.07 & 0.12 & 0.08 & \\
\hline $\mathrm{Cu}$ & 0.55 & 0.68 & 0.36 & 0.40 & 0.08 & 0.00 & 0.04 & 0.06 & 0.16 & 0.07 & 0.00 & 0.00 & 0.05 & 0.00 & 0.17 & \\
\hline Total & 100.86 & 99.92 & 101.59 & 100.88 & 101.18 & 101.22 & 101.35 & 101.16 & 101.25 & 101.23 & 101.14 & 100.70 & 100.12 & 100.56 & 100.94 & \\
\hline mole $\% \mathrm{FeS}$ & 12.61 & 12.60 & 12.30 & 12.18 & 11.51 & 11.74 & 11.42 & 11.49 & 11.86 & 12.39 & 11.76 & 11.42 & 10.23 & 10.27 & 11.66 & \\
\hline
\end{tabular}


Table 3. : Lead isotope compositions of Draa Sfar ores

\begin{tabular}{|c|c|c|c|c|c|c|c|c|c|c|}
\hline \multirow[t]{2}{*}{ Analyses } & \multirow[t]{2}{*}{ Location } & \multirow[t]{2}{*}{ Sample } & \multicolumn{3}{|c|}{ Isotopic ratios } & \multirow{2}{*}{$\frac{\mathrm{Pb}}{\overline{(\mathrm{ppm})}}$} & \multirow{2}{*}{$\frac{\mathrm{U}}{\overline{(\mathrm{ppm})}}$} & \multirow{2}{*}{$\begin{array}{l}\text { Th } \\
\text { (ppm) }\end{array}$} & \multirow{2}{*}{$\frac{\mu}{\left({ }^{238} \mathrm{U} /{ }^{204} \mathrm{~Pb}\right)}$} & \multirow{2}{*}{$\begin{array}{l}\mathrm{W} \\
\left({ }^{232} \mathrm{Th} /{ }^{204} \mathrm{~Pb}\right)\end{array}$} \\
\hline & & & ${ }^{206} \mathrm{~Pb} /{ }^{204} \mathrm{~Pb}$ & ${ }^{207} \mathrm{~Pb} /{ }^{204} \mathrm{~Pb}$ & ${ }^{208} \mathrm{~Pb} /{ }^{204} \mathrm{~Pb}$ & & & & & \\
\hline ACE3216 & $\begin{array}{l}\text { Draa Sfar — drill-hole } \\
\text { DDH } 18(95-98 \mathrm{~m})\end{array}$ & $\begin{array}{l}\text { Massive po with small amounts } \\
\text { of sp and gn ( } \mathrm{Zn} \text { lens) }\end{array}$ & 18.262 & 15.630 & 38.293 & 46300 & & & $\# 0$ & $\# 0$ \\
\hline ACE3215 & $\begin{array}{l}\text { Draa Sfar (north mine } \\
\text { waste) }\end{array}$ & $\begin{array}{l}\text { Massive po with small amounts } \\
\text { of sp and gn ( } \mathrm{Zn} \text { lens) }\end{array}$ & 18.263 & 15.630 & 38.298 & 38000 & & & \# 0 & \# 0 \\
\hline (1) & $\begin{array}{l}\text { Tazakourt DS 124, } \\
692.8 \mathrm{~m}\end{array}$ & $\begin{array}{l}\text { Zn lens - polymetallic } \\
\text { sulphides }\end{array}$ & 18.266 & 15.630 & 38.316 & 500 & $<4$ & 21 & 0.51 & 2.77 \\
\hline (1) & $\begin{array}{l}\text { Sidi M'Barek - DS } \\
125 \mathrm{a}, 345.7 \mathrm{~m}\end{array}$ & $\begin{array}{l}\text { Zn lens - po-sp- }(\mathrm{gn}) \\
\text { polymetallic ore }\end{array}$ & 18.586 & 15.657 & 38.891 & 683 & $<4$ & 8 & 0.38 & 0.78 \\
\hline (1) & $\begin{array}{l}\text { Sidi M'Barek - DS } \\
125 \mathrm{~b}, 404.5 \mathrm{~m}\end{array}$ & $\begin{array}{l}\text { Zn lens - po-sp- }-(\mathrm{gn}) \\
\text { polymetallic ore }\end{array}$ & 18.285 & 15.651 & 38.380 & 3788 & $<4$ & 9 & 0.07 & 0.16 \\
\hline (2) & $\begin{array}{l}\text { Sidi M'Barek - DS- } \\
125 \mathrm{~b}, 407.3 \mathrm{~m}\end{array}$ & $\begin{array}{l}\text { Zn lens - banded polymetallic } \\
\text { ore }\end{array}$ & 18.301 & 15.675 & 38.440 & 7200 & nd & nd & $\# 0$ & $\# 0$ \\
\hline (2) & $\begin{array}{l}\text { Sidi M'Barek - DS-139- } \\
\text { E5, } 600 \mathrm{~m}\end{array}$ & $\mathrm{Zn}$ lens - massive ore & 18.325 & 15.665 & 38.413 & 856 & nd & nd & & \\
\hline (2) & $\begin{array}{l}\text { Sidi M'Barek - DS-139- } \\
\text { E6, } 601 \mathrm{~m}\end{array}$ & Zn lens - massive ore & 18.776 & 15.681 & 38.441 & 942 & nd & nd & & \\
\hline (2) & $\begin{array}{l}\text { Sidi M'Barek — DS-139- } \\
\text { E7, 602.2m }\end{array}$ & Zn lens - massive ore & 18.351 & 15.669 & 38.449 & 15620 & nd & nd & & \\
\hline (2) & $\begin{array}{l}\text { Sidi M'Barek - DS-139- } \\
\text { E7, 603m }\end{array}$ & Zn lens - massive ore & 18.334 & 15.653 & 38.377 & 11253 & nd & nd & & \\
\hline (2) & Sidi M'Barek — DS-128- & $\mathrm{Cu}$ lens - contact massive & 18.797 & 15.687 & 39.702 & 436 & nd & nd & & \\
\hline
\end{tabular}




\begin{tabular}{|c|c|c|c|c|c|c|c|c|c|c|}
\hline \multirow[t]{2}{*}{ Analyses } & \multirow[t]{2}{*}{ Location } & \multirow[t]{2}{*}{ Sample } & \multicolumn{3}{|c|}{ Isotopic ratios } & \multirow{2}{*}{$\frac{\mathrm{Pb}}{}$} & \multirow{2}{*}{$\frac{U}{(\mathbf{U p m})}$} & \multirow{2}{*}{$\frac{\text { Th }}{}$} & \multirow{2}{*}{$\frac{\mu}{\left({ }^{238} \mathrm{U} /{ }^{204} \mathrm{~Pb}\right)}$} & \multirow{2}{*}{$\begin{array}{l}\mathrm{W} \\
\left({ }^{232} \mathrm{Th} /{ }^{204} \mathrm{~Pb}\right)\end{array}$} \\
\hline & & & ${ }^{206} \mathrm{~Pb} /{ }^{204} \mathrm{~Pb}$ & ${ }^{207} \mathrm{~Pb} /{ }^{204} \mathbf{P b}$ & ${ }^{208} \mathrm{~Pb} /{ }^{204} \mathrm{~Pb}$ & & & & & \\
\hline & $1,133.7 \mathrm{~m}$ & sulphides and py vein & & & & & & & & \\
\hline (2) & $\begin{array}{l}\text { Sidi M'Barek — DS-129- } \\
\text { M2, } 401 \mathrm{~m}\end{array}$ & $\begin{array}{l}\mathrm{Cu} \text { lens - massive po with } \mathrm{cp} \\
(0,5 \% \mathrm{Cu})\end{array}$ & 18.905 & 15.701 & 39.670 & 684 & nd & nd & & \\
\hline (2) & $\begin{array}{l}\text { Sidi M'Barek - DS-139- } \\
\text { E1, } 430.45 \mathrm{~m}\end{array}$ & $\mathrm{Cu}$ lens - massive ore & 18.749 & 15.686 & 38.959 & 1754 & nd & nd & & \\
\hline (2) & $\begin{array}{l}\text { Sidi M'Barek — DS-139- } \\
\text { E3, } 432.85 \mathrm{~m}\end{array}$ & $\mathrm{Cu}$ lens - massive ore & 19.010 & 15.691 & 39.541 & 1557 & nd & nd & & \\
\hline (2) & $\begin{array}{l}\text { Sidi M'Barek — DS-139- } \\
\text { E4, } 433.3 \mathrm{~m}\end{array}$ & $\begin{array}{l}\mathrm{Cu} \text { lens - cp stringers in } \\
\text { chlorite matrix }\end{array}$ & 18.687 & 15.681 & 39.091 & 393 & nd & nd & & \\
\hline (1) & $\begin{array}{l}\text { Sidi M'Barek — DS 128, } \\
139.5 \mathrm{~m}\end{array}$ & $\begin{array}{l}\mathrm{Cu} \text { lens }- \text { po and } \mathrm{cp} \\
\text { recrystallized ore }\end{array}$ & 18.790 & 15.673 & 39.051 & 329 & $<4$ & 8 & 0.78 & 1.62 \\
\hline (1) & $\begin{array}{l}\text { Gossan Sidi M'Barek - } \\
\text { DSR 1 }\end{array}$ & Hematite-goethite gossan & 18.846 & 15.658 & 39.255 & 447 & $<4$ & 10 & 0.58 & 1.49 \\
\hline (2) & $\begin{array}{l}\text { Sidi M'Barek - DS-128- } \\
\text { M12, } 133.5 \mathrm{~m}\end{array}$ & Quartz-py vein & 19.543 & 15.727 & 39.526 & 877 & nd & nd & & \\
\hline
\end{tabular}

(1) and (2) this study: (1): analyses performed by J.J. Peucat (University of Rennes France), (2): analyses performed by B. Cousens, Carleton University, Sudbury, Canada; ACE: A. Edwards (1989, unpublished data); U, Th and Pb contents have been measured in Guemassa laboratory by REMINEX division valorisation by X-ray fluorescence,

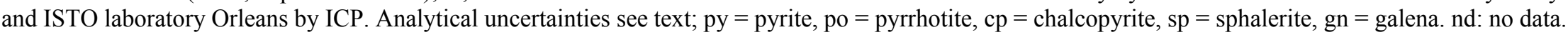


Table 4. : ${ }^{40} \mathrm{Ar} /{ }^{39} \mathrm{Ar}$ analytical data

\begin{tabular}{|c|c|c|c|c|c|}
\hline Step & ${ }^{40} \mathrm{Ar}_{\text {Atm. }}(\%)$ & ${ }^{39}$ ArK (\%) & ${ }^{37} \mathrm{ArCa} /{ }^{39} \mathrm{ArK}$ & ${ }^{40} \mathrm{Ar}^{*} /{ }^{39} \mathrm{ArK}$ & Age (Ma) \\
\hline \multicolumn{6}{|l|}{$D S F 3 G$} \\
\hline 1 & 95.1 & 1.3 & 0.00 & 49.74 & $427.9 \pm 197.7$ \\
\hline 2 & 82.3 & 3.1 & 5.26 & 32.25 & $288.7 \pm 106.2$ \\
\hline 3 & 97.6 & 3.6 & 5.83 & 20.22 & $186.4 \pm 89.0$ \\
\hline 4 & 88.3 & 28.4 & 10.60 & 36.94 & $327.1 \pm 15.8$ \\
\hline 5 & 67.8 & 28.3 & 64.36 & 37.26 & $329.7 \pm 12.0$ \\
\hline 6 & 43.9 & 10.2 & 38.18 & 37.97 & $335.4 \pm 29.6$ \\
\hline Fusion & 65.6 & 24.6 & 97.89 & 38.25 & $337.7 \pm 14.0$ \\
\hline \multicolumn{6}{|l|}{ DS57 } \\
\hline 1 & 74.9 & 0.8 & 0.18 & 12.05 & $113.3 \pm 28.6$ \\
\hline 2 & 5.9 & 5.2 & 0.51 & 17.32 & $160.8 \pm 11.7$ \\
\hline 3 & 4.9 & 11.7 & 0.01 & 27.80 & $251.5 \pm 1.9$ \\
\hline 4 & 2.2 & 8.7 & 0.04 & 49.23 & $424.0 \pm 3.4$ \\
\hline 5 & 4.6 & 18.5 & 0.14 & 37.77 & $333.8 \pm 1.6$ \\
\hline 6 & 3.4 & 9.0 & 0.12 & 36.51 & $323.6 \pm 2.7$ \\
\hline 7 & 3.0 & 24.5 & 0.08 & 37.42 & $331.0 \pm 1.6$ \\
\hline 8 & 3.7 & 7.4 & 0.27 & 38.99 & $343.6 \pm 3.5$ \\
\hline 9 & 2.2 & 11.2 & 0.43 & 39.97 & $351.5 \pm 2.1$ \\
\hline 10 & 0.0 & 1.9 & 1.60 & 44.81 & $389.7 \pm 8.5$ \\
\hline 11 & 2.6 & 0.7 & 5.77 & 47.96 & $414.3 \pm 24.7$ \\
\hline Fusion & 40.0 & 0.5 & 5.48 & 53.94 & $459.8 \pm 44.5$ \\
\hline
\end{tabular}

${ }^{40} \mathrm{Ar}_{\mathrm{atm}}=$ atmospheric ${ }^{40} \mathrm{Ar} .{ }^{40} \mathrm{Ar}^{*}=$ radiogenic ${ }^{40} \mathrm{Ar} . \mathrm{Ca}=$ produced by Ca-neutron interferences. $\mathrm{K}=$ produced by K-neutron interferences. Age $(\mathrm{Ma})=$ the date is calculated using the decay constants recommended by Steiger and Jäger (1977). The errors are at the 1 st level and do not include the error in the value of the $J$ parameter.

Correction factors for interfering isotopes produced by neutron irradiation in the McMaster reactor were $\left.\left({ }^{39} \mathrm{Ar}{ }^{37} \mathrm{Ar}\right) \mathrm{Ca}=7.06 \times 10^{-4},\left({ }^{36} \mathrm{Ar}{ }^{37} \mathrm{Ar}\right) \mathrm{Ca}=2.79 \times 10^{-4},{ }^{40} \mathrm{Ar}{ }^{39} \mathrm{Ar}\right) \mathrm{K}=2.97 \times 10^{-2}$. 